\title{
COMMENTS
}

\section{MOTIVE CRIMES AND OTHER MINDS}

\author{
ADAM CANDEub $\dagger$
}

\section{INTRODUCTION}

Early Sunday morning, March 3, 1991, after a car chase through the Los Angeles freeways, police officers ordered Rodney King to exit his car; King got out of the car and was ordered to lie down on the ground. ${ }^{1}$ A dozen officers soon surrounded him, and one, Stacey Koon, fired two shots from his stun gun at King's chest, without effect. ${ }^{2}$ Laurence Powell began to hit King repeatedly with a night stick as others joined in. King then rose to his knees and received ten quick baton blows. ${ }^{3}$ As if to ward off the onslaught, King raised his arm and then tumbled to the ground, falling on his stomach. ${ }^{4}$ In all, the officers hit the man at least forty times. ${ }^{5}$

On Wednesday, April 29, 1992, at the corner of Florence and Normandie Avenues in downtown Los Angeles, rioters stopped an eighteen-wheel truck and dragged its driver, Reginald Denny, out of the cab. Using his right leg, Keith Watson forced Denny's face down to the pavement as others beat him with a ball-peen hammer and other objects. Then, Damian Williams, at a range of three feet, threw a brick that smashed Denny's head. Williams then proceeded to dance what appeared to be a jubilant jig and left Denny bleeding

† B.A. 1990, Yale University; J.D. Candidate 1995, University of Pennsylvania. Thanks, as always, to my most valued editor, H.W.C. Thanks to the heroic efforts of the Law Review's Executive Editors: Adam Cutler, Chris Evison, Valerie Kelly, Sandy Stape and, especially, my good friends, Dan Dex and Jennifer Wolgemuth-whose editorial perspicacity often inspires awe. Thanks to Professors Arnold Enker, William Ewald, Michael Moore, and Stephen Morse for their valuable suggestions and comments; it should be noted that the views put forward in this Comment are not necessarily theirs, especially those views which are incorrect. A special note of sincerest gratitude to A.C.C.P.-B. for her patience, understanding, and affection.

I dedicate this Comment to my parents, Dr. and Mrs. Leon Candeub.

${ }^{1}$ See Hector Tobar \& Richard L. Colvin, Witnesses Depict Relentless Beating, L.A. TIMES, Mar. 7, 1991, at B1, B4 (describing King's beating in detail). B1.

${ }^{2}$ See Ted Rohrlich, Tried to Protect King, Briseno Says, L.A. TIMEs, Sept. 3, 1993, at

\footnotetext{
${ }^{3}$ See Tobar \& Colvin, supra note 1 , at B4.

${ }^{1}$ See id.

${ }^{5}$ See id.
} 
on the street. Later, Denny was rescued by a few brave local residents. ${ }^{6}$

Few images have etched themselves onto the American psyche as deeply as the videotapes of Rodney King's beating at the hands of Los Angeles police officers and Reginald Denny's beating, live on television, at the hands of the Los Angeles rioters. Significantly, the judicial resolution of both these atrocious crimes turned on questions of intent: Did Damian Williams intend to murder Denny with his brick? ${ }^{7}$ Did officers Koon and Powell intend to violate King's constitutional rights to be safe from the use of unreasonable force and to be protected from harm while in official custody? ${ }^{8}$

The central role of intent in these highly publicized trials led the subsequent public discussion into some unusual debates on the criminal law's intent requirement and, perhaps unknowingly, on basic issues regarding the philosophy of mind: How does one know what people are thinking or intending? What evidence can reasonably count in such a determination? Although theoretical and abstruse, these questions of determination often surfaced throughout the public debate.

For instance, on the television program MacNeil-Lehrer NewsHour, lawyer Barry Levin said: "The intent required [is one of] premeditated, willful, and deliberate ... first degree murder .... Mr. Williams did not bring a weapon to the scene of the crime.... There are many factors that go into the determination ... of proving intent beyond a reasonable doubt." 9 Professor Susan Estrich responded: "But when you hit somebody with a brick on the

${ }^{6}$ See Edward J. Boyer, TV Reporter Identifies Williams and Watson as Denny's Attackers, L.A. TimES, Sept. 4, 1993, at B1 (describing testimony furnished during the trial of Williams and another accused of attacking Denny by a radio and television reporter who broadcast live coverage of the L.A. riots); Marc Lacey \& Shawn Hubler, Rioters Set Fires, Loot Stores, L.A. Times, Apr. 30, 1992, at A1, A21 (describing the "gruesome scene[]" as reported by the "TV news helicopters").

${ }^{7}$ See Michael Hedges, L.A. Quiet After Verdicts: Denny Defendants Beat Serious Charges, WASH. TIMES, Oct. 19, 1993, at A1 ("Los Angeles Superior Court Judge John Ouderkirk ordered the jury to continue deliberations today on a charge that Williams attempted to murder Mr. Denny, [a charge] which could carry a life prison term.").

${ }^{8}$ See William H. Freivogel, Civil Rights Charges Camy Heavy Burden: Old Law Emphasizes 'Specific Intent' Rule, ST. LouIS POST-Dispatch, Apr. 15, 1993, at 1C. Laurence M. Powell and Stacey C. Koon were convicted under criminal civil rights provisions. See L.A. Police Sentences Explained, NAT'L L.J., Aug. 16, 1993, at 18; see also 18 U.S.C. \$ 242 (1988) (forbidding deprivation of civil rights under color of law "by reason of [a person's] color, or race").

${ }^{9}$ MacNeil-Lehrer NewsHour: Verdict (PBS television broadcast, Oct. 20, 1993). 
head, you generally intend to do them harm."10

In the pages of the Los Angeles Times, Professor Jerome Skolnick asked: "Could any juror, or any reader of this column, for that matter, confidently conclude, beyond a reasonable doubt, that Williams intended to put Denny to death or disfigure him with a blow by a brick?"11 George McCarty answered: "Given that Williams deliberately, willfully and maliciously smashed Denny's skull with that brick, could any fair, reasonable and rational person conclude otherwise?"12 As these two examples illustrate, an inference of intent from a particular individual's behavior can be as clear as day to some, but as cloudy as a Juneau afternoon to others.

Prosecutors used a variety of approaches to demonstrate to jurors the intents within the defendants' minds. In the federal trial of Rodney King, Barry Kowalski, who has "made a career of decoding for juries the subtle clues of such intent, ${ }^{13}$ advised the prosecution to concentrate on the officers' lies, in order to suggest that the police acted willfully and tried to cover it up. ${ }^{14}$ Similarly, in the Denny trial, Los Angeles Deputy District Attorney Janet Moore noted that she could not "cut open Mr. Williams' head to show you what he thinks.' ${ }^{15}$ Instead, she asked the jurors to look at circumstantial evidence like Williams's throwing, rather than tossing, the brick. ${ }^{16}$ Commenting on the trial, Professor Robert Pugsley asked, "How does one ever know what is in somebody's head? ... It's rough justice .... It's all kind of a mind-reading game that in no way can be seen as scientific, but it's the best we got." $" 17$

Obviously, something very odd is going on. Janet Moore certainly cannot cut into people's brains to see the intentions therein, but exactly how is throwing rather than tossing a brick evidence of anything? Or, how is lying an indication of past

${ }^{10} \mathrm{Id}$.

"Jerome H. Skolnick, Perspective on the Denny Verdicts: The People's Jury Did Its Job, L.A. TIMES, Oct. 22, 1993, at A11.

${ }^{12}$ George H. McCarty, Letter to the Editor, L.A. TiMEs, Oct. 30, 1993, at B7.

${ }^{13} \mathrm{Jim}$ Newton, The Strategy, the Fights, the Selbacks-How Four Driven Men Tackled One of the Most Explosive Criminal Trials of Modern Times, L.A. TIMES, June 27, 1993, (Magazine), at 11-12.

is See id.

${ }^{15}$ Edward J. Boyer \& Ashley Dunn, Williams, Watson Meant to Kill Denny, Prosecutor Says, L.A. Times, Sept. 29, 1993, at A1, A13.

${ }^{16}$ See id. at A13.

${ }^{17}$ Ashley Dunn, Tough Law, Tough Cases, L.A. Times, Sept. 24, 1993, at B1, B4. 
willfulness? If determining intent is like "a mind-reading game," what are the rules by which one plays?

While these highly controversial trials have focused national attention on the intent issue, legislators have been writing new laws that may ensure that the controversy surrounding intent stays on the national stage. In particular, many states have begun to pass hate-crimes statutes, ${ }^{18}$ and Congress is currently considering a federal hate-crimes statute. ${ }^{19}$ Moreover, Congress is also considering the Violence Against Women Act ("VAWA"). ${ }^{20}$ As this Comment will show, these laws require not only intent, which proved problematic enough in the Williams trial, but motive as well. Crimes of motive require more detailed findings of mental state and a deeper inspection of human motivation than other intent crimes. Therefore, the methods that juries use to determine intent under these statutes are a central issue: How will courts determine whether a particular word or gesture is indicative of intentional selection as required by Wisconsin law to enhance the penalty for hate-motivated crimes? ${ }^{21}$ How will a court under VAWA determine

${ }^{18}$ For instance, California's state hate-crimes statute provides:

No person ... shall ... willfully injure, intimidate, or interfere with, oppress, or threaten any other person in the free exercise or enjoyment of any right or privilege secured to him or her by the constitution or laws of this state or by the Constitution or laws of the United States because of the other person's race, color, religion, ancestry, national origin, disability, gender, or sexual orientation.

Cal. Penal Code $\S 422.6$ (a) (West 1988 \& Supp. 1994). For some other examples of state hate-crimes statutes, see CoLO. REV. STAT. $\$ 18-9-121$ (1) (Supp. 1993); CoNN. GEN. STAT. ANN. § 46(a)-58 (West 1986 \& Supp. 1993); IDAHO CODE § 18-7902(1987); MD. Code ANN., CRIM. LAW \$ 470A (1993); MASs. ANN. Laws ch. 22, § 16 (Law. Coop. 1991); MICH. COMP. LAWS ANN. \$750.147b (West 1991); N.Y. PENAL LAW $\S 240.30$ (McKinney 1989 \& Supp. 1994); N.D. CENT. CODE $\$ 12.1-14-04$ (1985); OHO Rev. Code ANN. § 2927.12 (Anderson 1993); OKLA. STAT. ANN. tit. 21, \$ 850 (West Supp. 1994); OR. ReV. STAT. \$ 166.155(c) (1990); PA. STAT. ANN. tit. 18, § 2710 (1983); R.I. GEN. LAWS § 11-42-3 (Supp. 1993); WASH. REV. CODE ANN. § 9A.36.080 (West 1988 \& Supp. 1994); W. VA. CODE § 61-6-21 (1992).

${ }^{19}$ See Hate Crimes Sentencing Act, H.R. 1152, 103d Cong., 1st Sess. (1993).

${ }^{20}$ See H.R. 3355, 103d Cong., 1st Sess., tits. $32-37$ (1993), reprinted in 139 ConG. REC. $\$ 17,095$ (daily ed. Nov. 26, 1993). The original bill was introduced on June 19 , 1990. See 136 CoNG. REC. S8263 (daily ed. June 19, 1990) (statement of Sen. Biden). The most recent version of VAWA, H.R. 3355, supra, "An Act to amend the Omnibus Crime Control and Safe Streets Act of 1968," is currently pending in Congress. In this Comment, my discussion of VAWA specifically refers to the civil rights section of this proposed act. See id. tit. 34.

${ }^{21}$ See WIS. STAT. ANN. § 939.645 (West Supp. 1993) (enhancing criminal sentences by a period of "not more than 5 years" for one who "[i]ntentionally selects the person against whom the crime . . . is committed . . . because of . . the race, religion, color, 
whether a rape or other violent crime was committed or "motivated by [the victim's] gender" ${ }^{22}$ when it can be so difficult to determine whether a person who hurls a brick at Reginald Denny's head was motivated by an intent to commit murder?

The criminal law's reliance on courts' abilities to read the minds of defendants is basic to the criminal law. ${ }^{23}$ It would be difficult, if not impossible, to imagine the criminal law without intent, purpose, knowledge, willfulness, or recklessness-all psychological qualities that require inquiry into the internal state of a defendant's mind. ${ }^{24}$ Moreover, general intuition tells us that in many cases reading other minds presents little difficulty. Few would consider controversial the claim that when $X$ smiles and extends his hand, he wants to meet you. Life would be difficult without such knowledge about other minds. ${ }^{25}$

Yet just as common sense dictates that some internal mental states are easily read, that same common sense similarly tells us that other internal mental states are nearly impossible to read: What was Hamlet thinking when he murdered Polonius as he cowered behind a tapestry in Queen Gertrude's closet? Did Hamlet really intend to stab a rat or was it part of Hamlet's ruse to make people think he was mad? Was he perhaps unconsciously using Polonius as a symbol for King Claudius and thus actually motivated by a longing for revenge?26 As the jurors at the trial of Reginald Denny's attackers

disability, sexual orientation, national origin or ancestry of the person"). The Supreme Court recently upheld the constitutionality of the Wisconsin statute. See Wisconsin v. Mitchell, 113 S. Ct. 2194, 2202 (1993); see also infra part IV.D (analyzing the Mitchell decision).

${ }^{22}$ H.R. 3355, supra note 20, §§ 3402(b), (d)(1).

${ }^{23}$ See MODEL PENAL CODE $\S 2.02$ (1962) (delineating the general requirements of culpability).

${ }^{24}$ Negligence is excluded, of course, because as usually understood by a formulation of the reasonable person standard, negligence requires no inquiry into internal mental states. This standard is determined and applied without reference to what the actor was thinking at the moment. See W. PAGE KEETON ET AL., Prosser AND KEETON ON THE LAW OF TORTS $\S 32$, at 173-74 (5th ed. 1984).

${ }^{25}$ See Stephen J. Morse, Diminished Capacity, in Action and Value IN THE Criminal LAW 239, 268 (Stephen Shute et al. eds., 1993) ("Relatively orderly and predictable human interaction is possible only because we are all able within reasonable limits to make inferences about our fellow humans' mental states from behavior ....").

${ }^{26}$ See William Shakespeare, Hamlet act III, sc. 4 (Yale Univ. Press, 1947). This Comment will return several times to this moment in the play. In this scene, Hamlet accuses his mother, Queen Gertrude, of gross impropriety for marrying his uncle Claudius less than two months after her husband (Hamlet's father) was murdered by Claudius-or so the ghost of Hamlet's father claims. The courtier, Polonius, hides 
discovered, troubling examples spring not only from literature.

This Comment looks to philosophy to see whether it provides any guideposts to determine which types of mental states can be inferred with confidence and which types cannot. Part I of the Comment demonstrates, on philosophical grounds, the difficulty in establishing certainty about internal mental states. The "other minds" problem ${ }^{27}$ is summarized, as is the problem's unsatisfactory solution as forwarded by the philosophical behaviorists. Drawing on Rudolf Carnap and Carl Hempel, ${ }^{28}$ Part I concludes that whatever knowledge about internal mental states actually exists must be derived by means of inference from behavior.

Part II of the Comment examines three ways to make such inferences. The first strategy employs the argument from analogy, which states that one can assume that others' minds work like one's own. The second method of inference utilizes the evidence offered by verbal utterances. It infers the intent present in the defendant's mind from the words uttered by the defendant. The dispositive nature of such evidence is questioned, and criteria for determining the accuracy of such inferences is developed. The third inferential method examines the evidence of the nature of the act itself. For instance, the evidence that $X$ answers the doorbell means he thought there was a visitor at his doorstep. In Part III, the types of mental states in which the law is interested are discussed.

After arguing that motives and intents are, in fact, different in Part IV, the Comment shows in Part V how motive crimes push the inferential strategies beyond a comfort level, beyond a point where such inferences can be considered valid. To demonstrate this point, motive crimes such as state hate-crimes statutes (of the sort recently upheld in Wisconsin $v$. Mitchell ${ }^{29}$ ) and the proposed Violence Against Women Act will be discussed.

behind an arris as he spies on Hamlet speaking to Queen Gertrude. When Hamlet discovers this ruse, he stabs Polonius through the arris, crying "How now! a rat? Dead, for a ducat, dead!" Id. at 108. To the delight of many a literature student, Hamlet's mental state at the time of this murder is most speculative and provides ample material for essay writing.

27 The other minds problem concerns determining whether other human beings have minds or are, in fact, automata. In a more general sense, the other minds problem questions the types of inferences-drawn from plyysical behavior-needed to justify knowledge claimed about other minds. See PAUL M. CHURCHLAND, MATTER AND CONSCIOUSNESS: A CONTEMPORARY INTRODUCTION TO THE PHILOSOPHY OF MIND $67-68$ (1984).

${ }^{28}$ See infra part I.B.

${ }^{29} 113$ S. Ct. 2194 (1993). 
This Comment concludes that, as a jurisprudential matter, laws which require determining intent and motivation to a high specificity present courts with decisions which cannot be made on a sound basis. Such laws, of which VAWA and hate-crimes statutes are particularly egregious examples, invite judges and juries to inject their own beliefs into the evidentiary vacuum which the motive requirements of these laws create. The imprecision of these laws also opens the possibility of punishing thought. These laws, therefore, threaten both the credibility and impartiality of the courtroom as well as freedom of thought.

\section{The Other Minds Problem And the Model Penal Code}

The jurors in the King and Denny trials were not the first to encounter the difficulties and intractabilities of determining motive and intent. In the nineteenth century, Oliver Wendell Holmes articulated the theory that as law matures, liability-civil and criminal-becomes more external and less reliant on mental state. ${ }^{30}$ Holmes stated that "commonly malice, intent, and negligence mean only that the danger was manifest to a greater or less degree. ${ }^{31}$

More recent theorists have echoed Holmes's call and have sought to limit the role of subjective, internal mental states. George Fletcher, in rejecting a more subjective, intention-based theory of criminal law, states that "the ground of punishment ... is something external that is attributed to the actor .... [T] his external element ... should be manifested, externally. ${ }^{n 32}$ Fletcher defends the necessity of an external act to criminality by stating one of this Comment's central assertions: "[T]he requirement of manifestly criminal conduct might be defended on evidentiary grounds .... It is so difficult to discern the subjective state of intending. ${ }^{n 33}$

Judge Richard Posner also has expressed discomfort with the notion of intent. He, like Holmes, envisions changing the law's intent requirements into terms of descriptions of external behavior, thereby obviating references to internal mental states:

We [can] examine the circumstances of the crime ... [and f]rom these circumstances a model of a deliberating criminal could be

so See Richard A. Posner, The Problems of JuRISPRudenCe 168 (1990) ("Holmes believed ... that the role of mental states in law diminishes as law becomes more sophisticated ....").

s1 Oliver W. Holmes, The Path of the Law, 10 HARv. L. REv. 457, 471 (1878).

${ }^{32}$ GeORGe P. Fletcher, RETHINKING CRIMINAL LAW $\$ 6.64$, at 470 (1978).

${ }^{33} \mathrm{Id}$. at 472 . 
construed-an "objective" reconstruction of the criminal's motivational experience .... It is thus possible ... to understand premeditation in behavioral terms .... The persistence of mentalist language in law may merely bespeak the cultural conservatism of the legal enterprise. ${ }^{34}$

Why are all of these distinguished jurisprudes so disturbed by the mentalistic language of the criminal law? Certainly, their discomfort has much to do with the difficulties in knowing what is going on in other minds. As Fletcher notes, "[it] is so difficult to discern the subjective state of intending. ${ }^{35}$

The problem in determining what is in another's mind is a perennial problem in philosophy, commonly called "the other minds problem." The issue can be put in several ways, most notably: How do we justify knowledge claims that other minds exist, or how do we justify knowledge claims "about the feelings, intentions, and cognitive style of other minds?" 36 Thus, the problem has two formulations: How do we know other minds exist, and how do we know what they are thinking? ${ }^{37}$ It is the latter problem which is of greatest import to the law.

Intents, beliefs, and other mental states are by their nature suspect classes because they are not physical entities, or at least neurophysiological research has yet to describe them in physical terms. Nobody has ever seen an intent or motive walk down the street, yet one can claim that $X$ had an intent to do $Y$. We speak about intents, motives, and internal mental states, yet we have no definite idea of what they are. What are these nonphysical entities that we speak about so casually?

While the nature of intent and motives and their relation to the physical world form the bread and butter of the philosophy of

${ }^{34}$ POSNER, supra note 30 , at 175-76.

${ }^{35}$ FLETCHER, supra note 32 , at 472.

${ }^{36}$ Thomas O. Buford, Introduction to EsSAYS ON OTHER MINDS ix, ix (Thomas O. Buford ed., 1970) (emphasis omitted).

${ }^{37}$ See William Hasker, Theories, Analogies, and Criteria, 8 AM. PHIL. Q. 242, 242 (1971). Hasker states:

The problem of other minds retains its place on the philosophical agenda, not because of a lingering doubt that perhaps after all one is only carrying on a monologue with a collection of automata, but because any theory of knowledge which cannot explain how we can know that other people feel, think and experience life subjectively is crucially deficient. 
mind $^{38}$ and date back at least to Descartes, ${ }^{39}$ the concern of the other minds problem is epistemological: How can one know or on what evidence can one justify knowledge about another's mind's intents and beliefs? It is this concern which seems to motivate a healthy portion of Holmes's, Fletcher's, and Posner's discomfort with the law's requirement of mental state-a concern made urgent by recent events like the Denny trial and the proliferation of hatecrimes statutes.

\section{A. The Other Minds Problem}

Why is knowing other minds so difficult? After all, everyone in everyday life presumes such knowledge: we know when others are angry, when others are lying, when others intend to hurt us, and when others love us. The problem, as many an unrequited, mistaken lover can tell us, is that we are often wrong. These errors are chronic because the method for inferring beliefs and intents in other minds is inherently inaccurate. Knowledge about other minds always involves inferences from and generalizations about people's behavior, words, or attitudes. These inferences and generalizations usually take the following form: $X$ ogles $Y$, then $Y$ infers that $X$ desires her sexually because, as a general rule, people who ogle are sexually desirous. The other minds problem, however, asks

how can one be justified in believing that the relevant psychobehavioral generalizations [in our example that people who ogle are generally sexually desirous] are true of other creatures, when all one can ever observe is one-half of the alleged connection: the creature's behavior [for example, the ogle]? The creature's mental states [for example, the internal, subjective mental state of being desirous] are directly observable only by the creature himself. ${ }^{40}$

This problem has been expressed in several propositions of the "other minds skeptic" who concludes that knowledge about other minds is impossible. ${ }^{41}$ First, mental events, like seeing red, tasting sacher torte, or desiring to kill one's law professor, are only fully experienced by the conscious subject who is seeing red, eating a

${ }^{38}$ See John D. Greenwood, Introduction: Folk Psychology and Scientific Psychology, in THE FUTURE OF FOLK PSYCHOLOGY: INTENTIONALITY AND COGNITIVE SCIENCE 1, 4 (John D. Greenwood ed., 1991) ("Contemporary philosophy of mind has moved ... [its interest] to intentional psychological phenomena such as beliefs and desires etc.").

${ }^{39}$ See CHURCHLAND, supra note 27 , at 8.

${ }^{40} \mathrm{Id}$. at 68 (emphasis omitted).

${ }^{41}$ See Buford, supra note 36 , at $\mathrm{x}-\mathrm{xv}$. 
sacher torte, or harboring murderous desires. As we all know, watching someone eat a sacher torte is not the same as eating it.

Second, mental events exist only when and only because "an individual mind has them; ${ }^{42}$ the phrase esse est percipi $i^{43}$ applies to mental events. One is hard pressed to describe what constitutes the experience of seeing red or tasting a sacher torte without some conscious being or entity actually doing the seeing or tasting.

Third, " $[\mathrm{m}]$ ental events and physical behavior are contingently related. ${ }^{n 4}$ This means that a headache does not automatically produce certain behaviors. There is no logical rule to conclude that the afflicted individual will clutch his head and moan, and there is no causal law which would require headache sufferers to clutch and moan. While relationships between certain mental states and certain behaviors no doubt exist (for example, happy people often smile, excited people often jump up and down, sexually intrigued people often ogle), there is no logical or causal law which mandates these relationships. This is intuitively obvious, for happy people do not always smile, excited people sometimes refrain from jumping up and down, and some sexually intrigued people do not ogle.

This proposition nonetheless is of great significance. We have no reliable method for inferring another person's internal mental state from his overt physical behavior. The Model Penal Code, however, assumes that we have that ability: it requires findings of mental states. ${ }^{45}$ Common sense indicates that we can infer each others' intents, subjective thoughts, and beliefs. Living in the world would be quite difficult if we did not have at least some knowledge of what was going on in other minds. ${ }^{46}$ There is evidence that even monkeys presume the existence of intents and beliefs in other monkeys. ${ }^{47}$ Thus, intentionality may not be the hallmark of human beings. Nonetheless, this knowledge is built on shaky principles.

There are two central conclusions to this discussion. First, one has no direct empirical or physical evidence and thus no direct

${ }^{42} I d$. at xi.

43 "To be is to be perceived."

${ }^{44}$ Buford, supra note 36 , at xi.

${ }^{45}$ See MOdel Penal CODE $\$ 2.02$ (delineating the general requirements of culpability).

${ }^{46}$ Imagine a world where you could not believe with certainty that your girlfriend or boyfriend loved you, where you could never conclude that another was angry at you, or where you could not conclude that a wave and smile meant your greeter was happy to see you. The other minds skeptic denies these types of knowledge.

${ }^{47}$ See Daniel C. DennetT, The Intentional Stance 238-39 (1990). 
knowledge of others' internal mental experiences; there is no accurate way, moreover, to infer such knowledge. (And even if such an inferential method were proposed, there would be no way to verify it.) Second, the criminal law and the Model Penal Code require such knowledge.

The following Sections present two responses to the other minds problem-solutions which would redescribe the mentalistic language of the Model Penal Code into verifiable physical phenomena. The first response seeks to describe internal mental states in terms of physical behavior similar to the program which Holmes and Posner suggest for the law. ${ }^{48}$ The second solution, which is suggested by Posner's remarks on the outdated metaphysics of the law, ${ }^{49}$ seeks to abolish the notion of mental states altogether. The failure of these two solutions suggests the continuing endurance of mentalistic language in the criminal law and the continuing need to check the validity of the inferences used to determine mental state.

\section{B. Philosophical Behaviorism's Answer to the Other Minds Problem}

In the 1930s and 1940s, Rudolf Carnap and Carl Hempel articulated the classic statements of philosophical behaviorism. ${ }^{50}$ Although not widely accepted today, ${ }^{51}$ physical behaviorism-or rather physical behavioristic approaches-have been popular among influential American legal theorists. ${ }^{52}$ Moreover, the tenets of physical behaviorism, which emphasize observable phenomena, underscore the assertion made in the previous Section ${ }^{53}$ that physical, observable behavior should serve as the basis for our judgments about internal mental states. Philosophical behaviorists think there is nothing meaningful to be stated beyond verifiable physical behavior. ${ }^{54}$ Thus, those who believe that statements about

${ }^{48}$ See supra notes $30-34$ and accompanying text.

${ }^{19}$ See supra note 34 and accompanying text.

${ }^{50}$ See generally Rudolf Carnap, Psychology in Physical Language, in LoGICAL PosITIVISM 165 (A.J. Ayer ed. \& George Schick trans., 1959); Carl G. Hempel, The Logical Analysis of Psychology, in 1 READINGS IN PHILOSOPHY OF PSYCHOLOGY 14 (Ned Block ed., 1980).

${ }^{51}$ In the words of Stephen Stich, philosophical behaviorism has suffered "the death of a thousand failures." STEPHEN STICH, FROM FOLK PSYCHOLOGY TO Cocnitive Science: The Case Against Belief 14 (1983).

${ }^{52}$ See supra note 31 and accompanying text.

${ }^{53}$ See supra part I.A.

${ }^{54}$ See Hempel, supra note 50, at 17 ("[A] statement for which one can indicate absolutely no conditions which would verify it, which is in principle incapable of confrontation with test conditions, is wholly devoid of content and without 
internal mental states are meaningful must recognize that their statements require inferences above and beyond mere empirical data.

\section{Statements About Internal Mental States, Which Are Nonphysical and Thus Unverifiable, Are Meaningless}

Carnap defines what he terms the "physical language" as the verifiable statements about the external world. ${ }^{55}$ Carnap further asserts that any meaningful law of psychology must be "translatable into physical language. ${ }^{56}$ Being a logical positivist, Carnap would consider only phenomena which are physically observable as truly verifiable phenomena. Those sentences which refer to nonphysical entities or to other sentences which, in turn, do not refer to physical phenomena are unverifiable and thus meaningless. ${ }^{57}$

Therefore, statements about beliefs, intents, or any internal mental state would be meaningless, because they would be inexpressible in the physical language. ${ }^{58}$ The statement "I am jealous" is, given the state of neurophysiological knowledge, irreducible to statements about the physical world. One cannot point to a particular configuration of neurons and say that it constituted jealousy. In everyday life and language, jealousy will always be referred to in subjective terms and perhaps for philosophical reasons never can be reduced to a particular neurological state. ${ }^{59}$

The problem with supposing internal mental states is that one must presuppose something beyond the verifiable (or at least the potentially verifiable, using an incredibly developed neurophysiological imaging apparatus) physical arrangement of neurons, such as the internal sensation of jealousy or the intent to smash someone's head with a brick. Carnap points out that these internal, mental experiences are nonphysical and doubts whether sentences uttered

meaning.").

${ }^{55}$ Carnap, supra note 50 , at 166 .

${ }^{56} \mathrm{Id}$. at 167.

${ }^{57}$ See id. at 180 (stating that a sentence is not "rendered meaningful by the fact" that it came from one's mouth).

${ }^{58}$ Carnap rejects the claims of phenomenology that psychological qualities can be known a priori or "on the basis of some single illustrative case." Id. at 168 .

${ }^{59}$ See ChuRChlAND, supra note 27, at 26 ("At present we do not know enough about the intricate functionings of the brain actually to state the relevant identities [between internal mental states like jealousy and their characteristic neurological substrate]."). 
about them can be verified. ${ }^{60}$ He promptly labels these sentences "meaningless" and consigns them to the realm of the metaphysical "pseudo-sentence."

\section{The Identification of Statements of Behavior with}

Statements About Internal Mental States

Carnap, however, does not despair of ever forming sentences about internal mental states of other minds. Instead, he denies that they are separate from physical behaviors and identifies internal mental states with physical behaviors themselves. ${ }^{62}$ Thus, when one says, "I am tired," what one really means is "I am displaying tired behavior."

Adopting such a view about internal mental states has obvious advantages to the law: jurors would no longer have to peer into subjective mental state-instead, they would merely observe behavior. Unlike internal mental states, behavior is public, unsubjective, and readily observable. By identifying internal mental states with behavior, one completely obviates the other minds problem. It comes as no surprise that commentators from Holmes onward have advocated approaches to mental state which could fairly be called behavioristic. ${ }^{63}$

\section{The Failures of Philosophical Behaviorism}

By defining internal mental states as behavior, philosophical behaviorism fails to grasp the essential nature of experience: If $X$ suffers pain stoically so that no one but he knows he experiences pain, is $X$ experiencing pain? Since the philosophical behaviorist is committed to defining pain as a behavior and $X$ is displaying no pain behavior, $X$ is not, by the philosophical behaviorist definition, in pain. In the end, the philosophical behaviorist's definition of mental states collapses into circularity: philosophical behaviorism seems merely to describe internal mental states in a term (behavior) which does not have much to do with internal state.

Another problem of philosophical behaviorism emerges from the justification of knowledge about one's own subjective mental states. How does $X$ know that he is angry? Following philosophical

\footnotetext{
${ }^{60}$ See Carnap, supra note 50, at 176.

${ }^{61} \mathrm{Id}$.

${ }^{62}$ See id. at 170 .

${ }^{6 s}$ See supra notes $30-31$ and accompanying text.
} 
behaviorism, $X$ must observe his own behavior and cannot rely on his own, internal feeling of being angry. ${ }^{64}$ This leads to the very odd conclusion that one cannot determine one's own mental state by introspectively asking oneself how one feels; one would have to observe one's own behavior. Thus, I would not be angry simply because I felt angry; I would be angry only if I displayed angry behavior.

Finally, philosophical behaviorism has problems handling mental states which ordinarily do not have any characteristic outward signs. Take, for instance, the problem of the mental state of "earnestly wants a cucumber sandwich." The philosophical behaviorists try to solve this problem by understanding such mental states as multitracked dispositions. ${ }^{65}$ One has the disposition "wants a cucumber sandwich" if (1) one would say "yes" to a waitress serving them, and (2) one would make them rather than peanut butter and jelly, and (3) one salivates when one sees them, and so forth. ${ }^{66}$ The problem is that defining the mental state "wants a cucumber sandwich" in terms of all its conditionals creates an infinitely long definition. ${ }^{67}$ Dispositional states, therefore, cannot be clearly and definitely stated, for their definitions contain potentially infinite elements. Therefore, the concreteness and clarity which the philosophical behaviorists gain by equating mental state with behavior or disposition disappears and is replaced by the inevitably vague and open-ended definitions of dispositional states.

In sum, philosophical behaviorism's circularity does not really say anything about mental state. ${ }^{68}$ Overt behavior or dispositions have no law-like or logical relationship to mental state. To say pain is a certain type of behavior simply defines pain in a certain way, nothing more: "[f]rom the statement ' $X$ has a pain' by itself no behavioral statement follows-not even a behavioral statement with a 'normally' or a 'probably' in it." The subjective sensation of

${ }^{64}$ See generally Paul Ziff, About Behaviorism, in ESSAYS ON OTHER MINDS, supra note 36, at 111. Ziff introduces this problem of philosophical behaviorism with the once famous joke of the two philosophical behaviorists who meet in the street. As a greeting, one says to the other, "You feel fine! How do I feel?" Id. at 111. Ziff, however, feels that both the objection to philosophical behaviorism and the joke are "bad." Id.

${ }^{65}$ See Churchland, supra note 27, at 23.

${ }^{66}$ See id.

${ }^{67}$ See id. at 25.

${ }^{68}$ See Hilary Putnam, Brains and Behavior, in 1 Readings In Philosophy of PSYCHOLOGY, supra note 50, at 24, 35.

${ }^{69}$ Id. at 30 . 
pain and pain behavior are different phenomena; one simply cannot define the former in terms of the latter without creating a circular, empty definition.

\section{Eliminative Materialism}

Another response to the other minds problem is simply to deny the existence of internal mental states or their effectiveness in controlling behavior. ${ }^{70}$ Like B.F. Skinner, ${ }^{71}$ the eliminative materialists understand human behavior without internal mental states. $^{72}$ They deny the "substantial set of laws or general state-

${ }^{70}$ See William Ramsey et al., Connectionism, Eliminativism, and the Future of Folk Psychology, in THE FUTURE OF FOLK PSYCHOLOGY, supra note 38, at 93, 99.

${ }^{71}$ See Andrew E. Lelling, Comment, Eliminative Materialism, Neuroscience and the Criminal Law, 141 U. PA. L. REv. 1471, 1487 (1993) (discussing Skinner's rejection of mentalistic approaches).

${ }^{72}$ Much of the eliminative materialists' writing has decried folk psychology (the notion that intents and beliefs exist and cause human behavior) simply because it dates back to Aristotle. See ARISTOTLE, Nicomachean Ethics, in INTRODUCTION TO ARISTOTLE 308, 478 (Richard McKeon ed. \& W.D. Ross trans., 1947). Folk psychology is therefore suspect and should be abandoned-just as Aristotelian physics has been abandoned. See generally Paul M. Churchland, Eliminative Materialism and the Propositional Attitudes, 78 J. PHIL. 67 (1981). The eliminative materialists, however, are not the first to decry traditional psychological metaphysics. They follow in a long tradition which includes, in this century, B.F. Skinner. See CHURCHLAND, supra note 27, at 90; Ramsey et al., supra note 70, at 95. Proponents of eliminative materialism clearly suggest that they are, at least in a general sense, following in his footsteps. See CHURCHLAND, supra note 27, at 91 .

Dislike of traditional psychological metaphysics has a distinguished history, extending as far back as Thomas Hobbes. "[F]or Hobbes mechanistic determinism has the last word, in the human as in the non-human sphere." 5 FREDERICK COPLESTON, A HISTORY OF PHILOSOPHY 23 (1961). I would, however, offer instead Julien Offray de La Mettrie, an author less well-known to the English-reading audience, as a grandfather of eliminative materialism. In his great work Man a Machine, which was aimed against the Cartesian concept of mind, he presents a mechanical view of man which, like the eliminative materialists, does not assert the existence of intent or belief-only mechanism. See JULIEN OFFRAY DE LA METTRIE, MAN A Machine 4, 10 (Gertrude C. Bussey et al. trans., Open Court Publishing, 1927) (1748). Interestingly, this work had a great influence on the Marquis de Sade. In the middle of Philosophy in the Bedroom, in between performing unspeakable acts of sexual perversion upon each other, the debauchees often discourse a philosophy remarkably similar to modern ethological theories of behavior, which, like eliminative materialism, do not posit the existence of intents and beliefs. See MARQUIS DE SADE, Philosophy in the Bedroom, in JUSTINE, PHILOSOPHY IN THE BEDROOM, AND OTHER WRITINGs 179, 360-61 (Richard Seaver \& Austryn Wainhouse eds. \& trans., Grove Weidenfeld 1965) (1795) ("Then act, Chevalier . . . were we to pulverize this whore, there'd not be a suspicion of crime in the thing: it is impossible for man to commit crime; when Nature inculcated in him the irresistible desire to commit crime . . . . [We are but $t$ ] he blind instruments of her inspirations, were she to order us to set fire 
ments connecting the various mental states with (1) other mental states, with (2) external circumstances, and with (3) overt behaviors." 73 Relying on advances in artificial intelligence, computer science, and cognitive science, the eliminative materialists deny the causal role of intents and beliefs in human behavior. ${ }^{74}$ Several models have been advanced to replace the semantic, propositional nature of traditional psychological paradigms. ${ }^{75}$ These models deny the causal efficacy of internal mental states like belief, intent, and desire and thus suggest ways complex, essentially nonphysical mentalistic experience can be reconciled with a universe ruled by material determinism. ${ }^{76}$ The eliminative materialists' claims are controversial and are still in their infancy; they by no means have won universal acceptance. ${ }^{77}$ If the eliminative materialist project is successful in describing and predicting human behavior in physical rather than in mental terms, the impact on the criminal law could be considerable. ${ }^{78}$

\section{The Other Minds Problem, Philosophical Behaviorism, ELIMINATIVE MATERIALISM, AND THE INEVITABILITY OF INFERRING INTERNAL MENTAL STATES}

Until (or if) eliminative materialism establishes the truth of its positions (dare we say "beliefs"), the criminal law will continue to utilize intents and beliefs; the Model Penal Code cannot do without them. ${ }^{79}$ Moreover, the physical behaviorist method of equating

to the universe ....").

${ }^{73}$ CHURChLAND, supra note 27 , at 58.

${ }^{74}$ For a searching analysis of eliminative matcrialism and its relationship to the law, see generally Lelling, supra note 71.

${ }^{75}$ See Ramsey et al., supra note 70, at 93. Ramsey describes a network where numerous input nodes connect to form an output node. Sixteen propositions were assigned specific numerical values for the input nodes. By weighting the intermediate nodes with appropriate values, the network was "trained-up" so that it gave values of one or near one for the true propositions, and zero or near zero for the false propositions. Thus, the network mimics semantic reasoning without ever possessing semantic representations. See id. at 106-10.

${ }^{76}$ See id.

${ }^{77}$ For a recent critique of materialist, computer-inspired approaches to understanding human mental functioning, see JOHN SEARLE, THE REDISCOVERY OF THE MIND (1993).

${ }^{78}$ Lelling has proposed two alternatives, the "character theory" and economicsbased theories, to replace the criminal law's mental state psychology. See Lelling, supra note 71, at 1531-36.

${ }^{79}$ See MODEL PENAL CODE $\$ 2.02$ (defining purpose, intent, and knowledge, which are all discrete, folk psychological mental states of the type which eliminative 
internal mental state with behavior has long been abandoned; thus, an analysis of mere behavior cannot yield knowledge about the mental states required by the law. This is a quandary: the criminal law requires knowledge about distinct mental entities which are not completely revealed in mere physical behavior, yet human beings have access only to mere physical behavior. ${ }^{80}$

We are thus inexorably led to the notion that whatever can be said about mental states must be inferred from behavior. Cast in a particularly unattractive philosophical behaviorist/eliminative materialist light, these inferences involve unverifiable and therefore meaningless statements about nonexistent, or at least epiphenomenal, entities. ${ }^{81}$ Whatever one's metaphysics, one is still left with the disjunction between behavior and mental states. Quine notes:

A mental state is not always manifested in behavior.... Thus the net result . . . is that the behavior provides incomplete and sporadic symptoms whereby to identify and distinguish various complex states of nerves....

Mental states .... are like diseases. A disease may be diagnosed in the light of observable signs though the guilty germ be still unknown ... ${ }^{82}$

If one assumes that beliefs and intents have some sort of existence and causal efficacy, then one is still left with the inference. ${ }^{83}$ On what basis do we infer mental states, or, to use Quine's language, what are the bases for the diagnoses of "incomplete and sporadic symptoms" of mental states? This is the vital question. Like philosophical behaviorists, jurors have only behavior with which to judge internal mental states. They must use their

materialism disparages).

${ }^{80}$ With the possible exception of telepathics and other psychics, human beings cannot, of course, read or know others' minds.

${ }^{81}$ The eliminative materialist need not deny the subject's experience of believing or intending. He merely claims that these internal mental states do not actually cause action. They are side effects of the neural networks which actually cause action. See Ramsey et al., supra note 70, at 96.

${ }^{82}$ W.V. Quine, Slates of Mind, 82 J. PHIL. 5, 6 (1985).

${ }^{85}$ Russell puts the point well:

It is probably possible theoretically to account for the behavior of living bodies by purely physical causal laws [as the behaviorists and eliminative materialists attempt to] .... If we are to believe that there are thoughts and feelings other than our own, that must be in virtue of some inference ... [which] must go beyond what is needed in physics.

Bertrand Russell, Analogy, in ESSAYS ON OTHER MINDS, supra note 36, at 3, 6. 
empirical evidence to infer into the unverifiable world of intent, belief, and purpose. The next Section will examine three possible inferential methods: inferences from analogy from one's own mind, inferences from words spoken by the actor, and inferences from an analysis of an act's function.

\section{A. The Argument from Analogy's Approach to Inferring the Content of Internal Mental States}

"The argument from analogy is the oldest of other minds arguments against skepticism [that other minds are unknowable to us]. ${ }^{\text {84 }}$ Certainly, it has an exalted pedigree which includes John Stuart Mill $^{85}$ and Bertrand Russell. ${ }^{86}$ The argument from analogy asserts the proposition that minds are knowable even though one does not sense the mind's sensations and thoughts. ${ }^{87}$ A.J. Ayer provides a succinct statement of the argument:

On the basis of my own experience I form a general hypothesis to the effect that certain physical phenomena are accompanied by certain feelings. When I observe that some other person is in the appropriate physical state, I am thereby enabled to infer that he is having these feelings; feelings which are similar to those that in similar circumstances I have myself. ${ }^{88}$

In general, this is the commonsense approach to the problem. One knows other minds largely because they must function as one's own. Russell wryly notes:

A philosopher might pretend to think that he knew only [a mind's physical, rather than semantic structure], but let him get cross with his wife and you will see that he does not regard her as a mere spatio-temporal edifice .... We are therefore justified in inferring that his skepticism is professional rather than sincere. ${ }^{89}$

Russell provides a clear rebuttal of this "professional skepticism."

Buford, supra note 36 , at xi.

85 See John S. Mill, An Examination of Sir William Hamilton's Philosophy 23 (4th ed. 1872) (stating that the mind "is to us unknowable").

${ }^{86}$ See Russell, supra note 83, at 3-8 (stating that our knowledge of others' thoughts and feelings is doubtful).

${ }^{87}$ See id. at 3.

${ }^{8}$ Alvin Plantinga, Induction and Other Minds, in ESSAYS ON OTHER MINDS, supra note 36, at 23, 23 (quoting A.J. AYER, THE Problem of KNOWLEdGe 249 (1956)).

${ }^{89}$ Russell, supra note 83 , at 3 . 
Yet it should be noted that Russell's main concern is justifying our beliefs about other minds' existence, not our beliefs about other minds' beliefs and intents. The argument easily lends itself to such an extension, as the quotation from Ayer indicates. In other words, one can justify knowledge about other minds in the same way that one justifies the belief that other minds exist.

\section{Russell's Argument from Analogy}

Russell states that "[t]he behavior of other people is in many ways analogous to our own, and we suppose that it must have analogous causes. What people say is what we should say if we had certain thoughts, and so we infer that they probably have these thoughts." ${ }^{90}$ Thus, in everyday life, in the commonsense philosophy, we assume that the human bodies around us, which look like us and act like us, in fact have similar internal mental reactions to things, even though we do not observe their internal mental functioning.

Russell perceives that the primary threat to the soundness of this inference is the possibility of "ingenious automata." Ingenious automata are mechanisms that mimic the behavior of thinking beings but are merely programmed machines or glorified calculators. Everyone else might be ingenious androids who seem to think and have internal mental reactions, but they are merely machines whose behavior is not governed by thought and mind but by physical mechanisms. Russell concludes, however, that there is a high probability that other minds exist. This probability increases as another person's observed behavior becomes more complex so that it can best be explained by assuming the existence of other minds. Russell states his conclusion in the following postulate:

If, whenever we can observe whether $A$ and $B$ are present or absent, we find that every case of $B$ has an $A$ as a causal antecedent, then it is probable that most $B$ 's have $A$ 's as causal antecedents, even in cases where observation does not enable us to know whether $A$ is present or not. ${ }^{92}$

${ }^{90} \mathrm{Id}$. at 4.

${ }^{91}$ Id. at 5 .

${ }^{92} \mathrm{Id}$. at 8 (emphasis omitted). 


\section{A Few Objections to the Argument from Analogy}

The philosophical behaviorists object to Russell's conclusion because it claims knowledge not based on observable phenomena. If it cannot be verified, it is meaningless. ${ }^{93}$ Currently, this approach is not taken too seriously, ${ }^{94}$ but its import for the law, I would maintain, still remains significant. Courts should require evidence to be fair by using methods that most citizens understand and accept. Placing a premium on observable, verifiable evidence is a good way for courts to fulfill that charge. The analogy argument inevitably leads the juror or judge to make the unverifiable assertion that the accused's mind works (or would work) as his own in a given situation. The accused's mind may work in a similar way-or it may not; one can never verify one's hunch on the matter..$^{95}$

A second, more sophisticated objection emerges when one asserts, using the analogy argument, that two minds have the same thought or sensation. ${ }^{96}$ Suppose that "she has a pain" means that she has the same internal mental reaction or sensation as when I have a pain. By what criteria can one establish sameness? How does one tell that my internal mental reaction or sensations are the same as yours? This problem can best be demonstrated by using Russell's own postulate. Russell claims that if we observe in ourselves a causal relation between a stimulus and a certain mental state (for example, if I eat a sacher torte, then I have an internal sensation of eating a sacher torte which I identify with almond crust and raspberry jam), then the same relationship will probably hold for other similar minds ${ }^{97}$ (for example, both you and I will react with the same or similar mental state when eating a sacher torte). But what does it mean to have two similar "sacher torte internal mental states"? What criteria would one use to determine the difference?

${ }^{93}$ See supra notes 55-57 and accompanying text.

94 See supra part I.B.3.

${ }^{95}$ For a rejection of the argument from analogy in the judicial process, see Kevin L. Keeler, Comment, Direct Evidence of State of Mind: A Philosophical Analysis of How Facts in Evidence Support Conclusions Regarding Mental State, 1985 WIS. L. REV. 435, 438-49. Instead of the argument from analogy, Keeler suggests a behaviorist approach similar to the one outlined earlier in this Comment. See supra part I.B.

${ }^{96}$ See Norman Malcolm, Knowledge of Other Minds, in ESSAYS ON OTHER MINDS, supra note 36, at 195, 197.

${ }_{97}$ See supra part II.A.1. 
The philosophical behaviorists solve this problem by simply adopting behavior as the criterion for determining similar mental states: the same mental state is the same type of behavior. ${ }^{98}$ They, therefore, have no need for the analogical argument. On the other hand, the analogical argument does not have a criterion for determining what is sameness. ${ }^{99}$ How can one determine whether my sensation in my mind is the same as your sensation in your mind? Certainly, one has a criterion for sameness in shape (all squares have four sides arranged at right angles) and in sound (the same decibel level and digital characterization). But how does one establish the same mental state? ${ }^{100}$

Moreover, the argument from analogy requires an induction from one case, that is, what is going in the analogizer's mind. This is the weakest type of induction, "comparable to inferring that all bears are white on the strength of observing a single bear (a polar bear). ${ }^{n 101}$

\section{A Final Argument Against Analogy}

There is a final problem in the argument from analogy, namely "that one learns from one's own case what thinking, feeling, [and] sensation are." 102 Russell makes this assumption: "We observe in ourselves such occurrences as remembering, reasoning, feeling pleasure, and feeling pain. We think that sticks and stones do not

${ }^{98}$ See supra part I.B.2.

${ }^{99}$ See Malcolm, supra note 96, at 197 ("If I do not know how to establish that someone has a pain then I do not know how to establish that he has the same as I have when I have a pain."). Here Malcolm employs the criteriological definition of meaning which states that "[the] observable characteristics by which one identifies an object as an instance of some descriptive expression are . . "criteria." Carl Wellman, Wittgenstein's Conception of a Criterion, in WITTCENSTEIN AND THE PROBLEM OF OTHER MINDS 154, 157 (Harold Morick ed., 1981). Thus, there are no sure criteria for the application of a word which refers to intent, belief, or any other feature in the mentalistic language, for one cannot find observable characteristics which could establish "sameness."

${ }^{100}$ See Malcolm, supra note 96 , at 195 . This idea can be further elucidated by distinguishing between a symptom and a criterion: "Criteria are observable features which are directly connected to an expression by its meaning; symptoms are features which are indirectly connected to the expression by being associated with the criteria in our experience." Wellman, supra note 99, at 159 . In a way, mental states have no criteria; they only have symptoms. For similar comments on symptoms and mental states, see generally Quine, supra note 82 .

${ }^{101}$ Churchland, supra note 27, at 69.

102 Malcolm, supra note 96, at 202 (emphasis omitted). 
have these experiences, but that other people do." 103 He would assert that our own experiences teach us what the pleasure or pain of any particular sensation is.

Drawing on Wittgenstein, Malcolm rejects this assertion. Following Russell-and the commonsense approach-one learns what pain is from one's own inward experience of pain. One learns what pleasure is from experiencing the eating of a sacher torte. Yet how does one know that one is right? One could be identifying pleasure with pain and vice-versa: "Suppose that [one] identified the emotion of anxiety as the sensation of pain? Neither he nor anyone else could know about this 'mistake.' . . . The inward identification cannot hit the bull's-eye, or miss it either, because there is no bull'seye." 104

Thus, the argument from analogy hardly gets off the ground because one really cannot be confident that one is properly identifying those mental properties-in one's own mind-which one is analogizing into another's.

\section{The Analogical Argument and the Law}

The main point of the preceding discussion is that the commonsense approach that one can somehow project his own mind onto the mind of another is suspect. Nevertheless, it is the way most of us, including judges and juries, infer the intent of others' behavior and words. ${ }^{105}$

There are several limitations to the analogy argument which bear particularly on legal settings. First, by its own premises, the analogical argument requires that the mind-bearing entities be similarly constituted. It makes sense to assume that one mind works like another only if both are similar in physical structure. $A$ presumes $B$ 's mind works like his own at least partly because $A$ and $B$ resemble each other physically, that is, both are members of the human species, and similar physical structures tend to work similarly. ${ }^{106}$ Thus, the accuracy of the analogy depends on the degree of similarity between the two minds because one would expect that just as physically similar objects act similarly, physically

${ }^{103}$ Russell, supra note 83 , at 4.

${ }^{104}$ Malcolm, supra note 96, at 204.

${ }^{105}$ See Keeler, supra note 95 , at 435.

${ }^{106}$ Russell is explicit about this point. "I infer that other people's bodies are associated with minds, which resemble mine in proportion as their bodily behavior resembles my own." Russell, supra note 83 , at 7 . 
dissimilar objects act dissimilarly. Strictly applying this logic, one might conclude that minds which share similar histories, experiences, and backgrounds make the best judgments and determinations about each other's mental state. Common sense bears this out: spouses and family members who have spent their lives together often have uncanny abilities to read each other's minds. Complete strangers have greater difficulty reading each other's minds.

Second, the argument from analogy, if taken to its extreme, would reasonably allow one to ascribe to other minds "only what one finds in one's own mind." 107 This limitation would exclude colorblind people from "believ[ing] that other humans have visual sensations." 108 A colorblind person cannot analogize the internal mental state of seeing blue if he has never had the internal mental state of seeing blue.

Thus, the argument from analogy seems perfectly acceptable for the judging of common experiences we all share but perhaps less suitable for more complex experiences. One could use the analogy argument to be confident that one's girlfriend is more than a mechanized doll, but not necessarily to infer what $\mathrm{Hamlet}^{109}$ was thinking when he stabbed Polonius. ${ }^{110}$ Why? Because while we all share general mental states like consciousness, hunger, pain, or jealousy, we do not all share more complex states, like those of a disinherited, cerebral, and overweight Danish prince who communicates with dead relatives, suffers Oedipal tensions, and is planning to skewer the father of his beloved Ophelia. Like the above argument about colorblindness, one can analogize only those sensations and mental states which one experiences. Almost all of us experience sight, hearing, and smell. One can, therefore, conclude that other minds see, hear, and smell as one's own. We all do not share, however, Hamlet's angst; analogizing our minds onto his mind is, therefore, of limited value.

The most disturbing upshot is that jurors who are more similar to the defendant can best make judgments about his mental state. One might conclude that only female jurors can best determine female defendants' mental states, that wealthy WASPs can best

${ }^{107} I d$.

${ }^{108} \mathrm{Id}$.

${ }^{109}$ Like Prufrock, "I am not Prince Hamlet, nor was meant to be." T.S. EL.IOT, The Love Song of J. Alfred Prufrock, in COLLECTED POEMS 1909-1935, at 16 (1936).

${ }^{110}$ See SHAKESPEARE, supra note 26, act 3, sc. 4. 
determine the mental states of other wealthy WASPs, and so forth. In short, the greater the difference in the experiences of the accused and the jurors, the less qualified they are to determine the accused's mental states. This last problem demonstrates that analogy serves as an incomplete inferential strategy for the law.

\section{B. Quine's Funny Bunny: Inferring Internal Mental State Through Verbal Evidence}

Another way to infer the mental states of others is through verbal evidence. Common sense would say that one who exclaims "I'm going to kill that man" and then reaches for his revolver generally has the internal mental state of intending to kill. Using verbal evidence to determine internal mental state, however, is not simple because a speaker's intent regarding the meaning of a word he utters is often indeterminate. Moreover, even if one determines a speaker's intended meaning, this does not prove motivation-as VAWA and hate-crimes legislation require. An attacker may mean by his utterance "I hate you because you belong to a certain group." Such a statement might support the inference that the speaker is racist, but that does not mean that the particular attack is motivated by his hate. ${ }^{111}$

This problem is evident in determining the meaning of hateful epithets. The legislative history of VAWA ${ }^{112}$ and judicial decisions on hate crimes ${ }^{113}$ show the importance of epithets in determining intent. The burden of this Section will be to show the difficulties of demonstrating what any word-and especially an epithet-means

111 Wigmore is quite explicit on this point. "Since the Intention, offered to evidence an Act, becomes in its turn an interim probandum, there is thus always a double inference involved, first from the conduct, etc. to the intention, and then from the intention to the act." JOHN H. WIGMORE, THE SCIENCE OF JUDICIAL PROOF $§ 102$ (3d ed. 1937).

With language, there is a triple inference to determine mental state. As will be shown in the following test, one must first determine the meaning of an utterance or epithet, then infer a mental state of hate from the utterance, and, finally, use the inferred mental state of hate to prove circumstantially that the same mental state of hate actually caused the criminal act.

112 See S. REP. NO. 197, 102d Cong., 1st Sess. 50 (1991) (stating that one of three proofs of gender motivation would be uttering "antiwomen epithets," just as racial epithets are used to show civil rights violations of racially motivated attacks). This idea was expressed again in the report accompanying the 1993 version of VAWA. See S. REP. No. 138, 103d Cong., 1st Sess. 51 (1993).

${ }^{113}$ See, e.g., Commonwealth v. Rink, 574 A.2d 1078, 1081 (Pa. Super. Ct. 1990) ("We are not persuaded by appellant's rationalization that the ethnic epithets were not racially motivated but were the result of emotionally charged behavior."). 
to the speaker. Since hate crimes (and perhaps VAWA) have intent requirements, one must determine not what an epithet means, but what the defendant meant by the epithet. Moreover, even if one establishes what the speaker meant by the epithet, such knowledge does not establish whether the speaker was motivated by hate or antiwoman bias, a requirement of many of the hate-crimes statutes $^{114}$ and VAWA. ${ }^{115} \mathrm{~A}$ bigot can commit an act because he is a bigot-or for other reasons. That he expresses that he is a bigot before committing a crime is merely circumstantial evidence that his crime was committed because of bigotry.

\section{Quine's Theory of Radical Translation}

Quine's theory of radical translation ${ }^{116}$ presents the basic problem with inferring another's intended meaning from his spoken word. His argument suggests that it is impossible to ascertain that speaker $A$ and listener $B$ derive or intend the same meaning from the same word. Thus, Quine asserts that any manual of translation between two languages is indeterminate. ${ }^{117}$ In other words, one can never be positive that word $X$ in language $A$ translates to word $Y$ in language $B$. Language has a limited ability to communicate $A$ 's meaning or sense of a word to person $B$ who must somehow interpret the word to get at $A$ 's meaning. The threat of radical translation (Quine's phrase for the notion that a word's meaning can never be ascertained with absolute confidence) is that there are no absolute assurances that two parties are referring to the same thing when they use the same word even if they are speaking the same language.

To demonstrate this thesis, Quine uses his famous example of the anthropological linguist who observes a native group in order to learn their language: "A rabbit scurries by, the native says 'Gavagai', and the linguist notes down the sentence 'Rabbit' (or 'Lo, a rabbit') as tentative translation ...." 118

How does the linguist know that the native, when he says "gavagai," does not refer to flies which surround the rabbit, or only

${ }^{114}$ See supra note 18 and accompanying text.

115 See infra part IV.B.

${ }^{116}$ See WILLARD V.O. QUINE, WORD AND OBJECT 26-79 (1960); see also DONALD DAVIDSON, INQUIRIES INTO TRUTH AND INTERPRETATION 125-40 (1984); 1 DAVID LEwIS, Radical Interpretation, in PHILOSOPHICAL PAPERS 108, 108-21 (1983).

${ }^{117}$ See QUINE, supra note 116 , at 27.

${ }^{118} I d$. at 29. 
to white rabbits, or to rabbits jumping towards the right on Tuesday mornings? Quine saves the Berlitz language school by noting that the linguist could winnow out the meaning of "gavagai" by continued observation of its use, eliminating uses which were discrepant to the linguist's understanding. Thus, if the "stimulus meaning" of a word does not vary from occasion to occasion, then these "stimulus meanings may without fear of contradiction be said to do full justice to their meanings. ${ }^{\text {119 }}$

Quine introduces the notion of observationality and defines the notion as a "degree of constancy of stimulus meaning from speaker to speaker." 120 Observationality is a concept which comes in degrees. ${ }^{121}$ On the extreme of high observationality, with words like "red," changes in meaning over different contexts are not significant. One could imagine the linguist and native coming to few confusions about the word "red." At the other extreme, however, consider the word "bachelor," whose meaning would be very difficult to ascertain over numerous occasion meanings ${ }^{122}$ and stimulus meanings.

Everyday life supports this argument. Say two people disagree about the color of a shirt, one claiming that it is red, the other claiming that it is pink. They could quickly resolve the dispute by noting that their meanings of red differ. "Is this shirt red to you?" $B$ asks $A$. If $A$ 's answer is yes, $B$ learns that $A$ means "red" to include the particular hue the shirt possesses. Try the experiment with "bachelor," however. Say $A$ and $B$ disagree as to whether $X$ is a bachelor. At what will $A$ and $B$ point to understand their respective meanings of bachelor? Bachelor has low observationality simply because its meaning is not easily established by "gavagai"-like experiments in the world.

Words with high observationality have meanings which are more easily determinable through "gavagai"-like experiments. The reverse will be true with words with low observationality. Moreover, low observationality will produce odd and discrepant occasion sentences ${ }^{123}$-like having some unmarried men called bachelors, but

${ }^{119}$ Id. at 42 . Stimulus meaning is a Quinean term of art referring to the disposition to dissent or assent which the linguist elicits when he points to the rabbit and asks, "gavagai?" Id. at 34 .

120 Id. at 43.

${ }^{121}$ See id. at $42-44$.

122 "Occasion meaning" is another Quinean term used to describe a word's meaning at a particular time it is used. See id.

123 "Occasion sentence" is a Quinean term which refers to sentences that "com- 
not other unmarried men, like priests. ${ }^{124}$ Words with low observationality will have a "wide intersubjective variability of stimulus meaning, ${ }^{125}$ and their meaning will be more difficult to ascertain. Thus, Quine presents a scale of observationality. ${ }^{126}$ While one can never be sure of the meaning of another speaker's words, some words will more readily allow agreement of application.

\section{Applying Quine's Radical Translation to the Determination of Intended Meaning}

Although Quine never resolves the problem of radical interpretation's indeterminacy, observationality suggests that the more times one sees a word used, the clearer its application becomes. ${ }^{127}$ Applying Quine's story of the linguist and the native to the problem of intended meaning, one might surmise that the stimulus meaning of intent is very difficult to ascertain. Unlike with rabbits, one cannot point at anything because intents and beliefs are nonphysical. Indeed, internal mental states would have a very low observationality, and it is not clear whether one could ever have a proper translation. Quine notes that "[i]n practice, of course, the natural expectation that the natives will have a brief expression for 'Rabbit' counts overwhelmingly." 128 In short, we expect that a certain word refers to a certain concept because we already have a concept for that word. We tend to translate "gavagai" as rabbit because we have a word "rabbit," but we do not have a word for the concept of a "white bunny jumping to the right in midmorning."

Thus, one could claim that ascriptions of intent to other mindswhich have very low observationality-are more the imposition of our concepts of intent rather than any response to observed empirical data. This implies that we receive knowledge of others'

mand assent or dissent only if queried after an appropriate prompting stimulation." Id. at 35-36.

${ }^{124}$ Few, I assert, would call a priest a bachelor.

$125 \mathrm{Id}$. at 45.

${ }^{126}$ See $i d$. This is admittedly an oversimplification. Quine was truly skeptical about whether any intentional system can be determinate-of whether one can truly tell what another really believes. See DENNETT, supra note 47 , at 40 (" $[\mathrm{I}] \mathrm{t}$ is always possible in principle for rival intentional stance interpretations . . . to tie for first place, so that no further fact could settle what the intentional system in question really believed."). Nonetheless, Quine's "gavagai" experiments do suggest how human beings approximate each others' meanings and thus can be fruitfully applied in cases where a speaker's meaning is obscure.

${ }^{127}$ See QUINE, supra note 116 , at 42.

${ }^{128} \mathrm{Id}$. at 40. 
internal mental states from analogy. Due to the low observationality of internal mental states, we export or analogize our concepts of mental states (which we receive exclusively from our own individual, subjective experience) onto other minds.

\section{Application to a Legal Setting: Determining Meaning}

The preceding discussion casts doubt on the nature of verbal evidence to support a certain conclusion about a defendant's intended meaning and his mental state. Consider the "water buffalo incident" which occurred at the University of Pennsylvania in January 1993 and dragged on throughout the school year. ${ }^{129}$ A student yelled "water buffalo" out of the window at a group of African American women who were involved in a loud sorority activity. ${ }^{130}$ The shouting student, Eden Jacobowitz, was charged with violating the university's ban on hate speech. ${ }^{131}$ The question facing the university tribunal was whether the student intended to demean the women and inflict direct injury. ${ }^{132}$ This question, in turn, depended on what "water buffalo" meant to the speaker. The speaker claimed that water buffalo meant, to him, "behema."133 Behema is the Hebrew word for water buffalo, which also means a rude, inconsiderate individual. The Judicial Inquiry Officer, Robin Read, thought the term referred to animals found in Africa and thus deemed the remark racist. ${ }^{134}$

Under a Quinean paradigm, one would discover the speaker's meaning by eliciting stimulus meanings. ${ }^{135}$ In an ideal world one

${ }^{129}$ See Howard Goodman, At Penn, an Appeal for Quiet Brings Speech Issue to the Fore, PHILA. INQUIRER, Apr. 27, 1993, at B4.

${ }^{130}$ For a discussion of the incident, see generally Howard Goodman, At End of Hate-Speech Hearing at Penn, No One's Allowed to Talk, PHILA. InQUIRER, May 17, 1993, at A1.

${ }^{131}$ See Goodman, supra note 129, at B4 ("Jacobowitz soon found himself on the receiving end of racial harassment charges.").

132 The University of Pennsylvania defines "racial harassment" as

any verbal or symbolic behavior that . . . is intended by the speaker or actor only to inflict direct injury on the person or persons to whom the behavior is directed; or is sufficiently abusive or demeaning that a reasonable, disinterested observer would conclude that the behavior is so intended; or occurs in a context such that an intent only to inflict direct injury may reasonably be inferred.

UNIVERSTTY OF PENNSYLVANIA, UNIVERSTTY POLICIES AND PROCEDURES 1992-1994, at 6.

${ }^{133}$ Goodman, supra note 129 , at B4.

${ }^{134}$ See id. Read was mistaken, at the very least, in her zoology.

135 See supra note 119 and accompanying text. 
would present the speaker with numerous stimuli to determine what "water buffalo" means. First, one would point to a group of African American women and say "water buffalo." Next, one would point to a group of rude, inconsiderate people and say "water buffalo." Based on the type, number, and range of stimulus meanings elicited, one could with some confidence determine the meaning of "water buffalo" as meant by the speaker.

Without Quine's experiment, one simply cannot fix the meaning of another's speech. Of course, commonly used words present few problems of radical translation, at least for nonphilosophers. Words on the borderline-those words that are not in common use or those uttered by speakers of different languages ${ }^{136}$-require a translation. As the above example shows, racial epithets can sometimes fall into this category.

\section{David Lewis and Intended Meaning: Does Radical Interpretation Collapse into the Argument from Analogy?}

David Lewis provides an excellent dissection of the issues of radical translation and interpretation, which illuminates the types of knowledge needed to make inferences about another's mind from verbal evidence. ${ }^{137}$ Without Quine-like "gavagai" experiments, Lewis points out that assumptions about other minds must be made in order to understand language. He makes the vital point that not only must one assume, as Quine notes, that the intended meaning of a speaker's word is far from immediately apparent, but also that in order to arrive at another's intended meaning, we must ascribe our own beliefs and desires onto another person. ${ }^{138}$

\section{The Principle of Charity}

Lewis calls this requirement the "Principle of Charity," 139 and formulates it in the following way: "[T]here must exist some common inductive method $M$ which would lead to approximately our present systems of belief if given our life histories of evidence, and which would likewise lead to approximately the present system

${ }^{136}$ Interestingly, as mentioned above, Eden Jacobowitz was, in a way, using Hebrew, a foreign language.

${ }^{137}$ See LEwIS, supra note 116, at 108-18.

${ }^{138}$ See id. at 112-13.

${ }^{139}$ Id. at 113 . 
of beliefs ascribed [by us to other people]." 140 The reason the Principle of Charity is needed to arrive at others' meaning is simply because, considering others simply as "physical system[s],"141 we have no access to their beliefs and desires and, therefore, without the Principle, we cannot even begin to guess at which beliefs and ideas another individual means his words to represent. Consider the following example: Pierre looks at a Napoleon pastry and starts drooling, and Pierre says "yum, yum." We can believe that "yum, yum" means "I believe the pastry is delicieux" because the Principle of Charity allows us to assume that if I were to look at a Napoleon pastry and say "yum, yum," I, like Pierre, would find the pastry delicious. In other words, there must be an inductive principle (which Lewis calls " $M^{\text {"142) }}$ ) which will insure that both you and Pierre would react similarly given the same physical environments. Without this inductive principle, one would have no way of deciding whether "yum, yum" meant "c'est delicieux" or "c'est merde."

$M$, the Principle of Charity, is really a sort of analogical argument which asserts that you or I would experience the same internal mental reactions to the same environment or external stimuli. As such, $M$ is open to the same problems of the analogical argument that come dramatically to mind with the water buffalo example. What Eden Jacobowitz meant when he said "water buffalo" is difficult to ascertain because we are uncertain when we infer our mental states onto another-because, in short, the argument from analogy is limited.

2. Language, Meaning, Intended Meaning, and Intent

We return to the argument from analogy and discover that language is not a perfect vehicle to discover the internal mental states of others. It is the burden of the above argument that to arrive at the meaning of others' words one must first assume, by the argument from analogy, a degree of knowledge about other minds. Thus, words cannot convey internal mental states dispositively, for to understand words' meanings, one must make assumptions about other minds. One would be quite justified, therefore, to doubt the

${ }^{140} \mathrm{Id}$.

14I Id. at 108. By physical system, I take Lewis to mean that we have no direct access to other minds and must judge their beliefs and intentions purely on their physical behavior.

142 Id. at 113. 
use of epithets to demonstrate that the speaker harbors ethnic or racial animus, because their meaning is often opaque.

Last, it should be remembered that even if one were to establish as racist the meaning of a word or phrase, such as "water buffalo," as meant by the speaker, this would merely establish the speaker as a racist, not that whatever crime committed subsequent to the comment was motivated by racial animus. It would merely be circumstantial evidence of such motivation, and it is the motivation which laws may constitutionally punish, not the bigotry. ${ }^{143}$ As an evidentiary concern for hate crimes, it presents us with a considerable problem: how to distinguish between the bigot who uttered epithets but was not motivated by bigotry and the bigot who was actually motivated by bias. It seems that given the evidence potentially available, such a distinction may often be impossible to make.

\section{Functional Analysis}

Common sense interrupts the discussion. Surely, one can decide another's mental state from the particular circumstances and the particular kind of act being done: people who answer doorbells generally have the mental state of belief that there are visitors, those who open books and sit down in easy chairs generally intend to read, and so on. Certain acts require and entail having certain mental functions. When a pianist plays a concerto and makes all his entrances correctly, one can conclude that his subjective mental state includes the knowledge both of the concerto and the place at which the orchestra is playing.

The California Code of Evidence presumes general intent; one is presumed "to intend the ordinary consequences of his voluntary act." ${ }^{144}$ This underscores the notion that the simple doing of an act entails that the actor intend to do that act. The California Code of Evidence, however, does not presume "specific intent." 145 This is because specific intent is not necessarily part of doing a particular act; the act could very conceivably be done with different mental states. Thus, for prosecution for assault with intent to murder, the

${ }^{143}$ See Wisconsin v. Mitchell, 113 S. Ct. 2194, 2200 (1993) (stating that a defendant's abstract beliefs may not be taken into consideration by a sentencing judge). See infra part IV.D for a discussion of the constitutional requirements of bias motivation.

${ }^{141}$ CAL. Evid. Code $\$ 665$ (West 1966 \& Supp. 1994).

${ }^{145} I d$. 
mere act itself is not dispositive of mental state, because the act could be committed with numerous mental states. ${ }^{146}$

The proponents of motive crimes and hate-crimes statutes assume that given the circumstances of a particular incident, mental state will be readable-or, at least, that is the notion behind the "totality of the circumstances" test that is so often urged for motive crimes. ${ }^{147}$ As the totality of circumstances argument goes, one will understand the function and purpose with which an act was doneand thus the accompanying mental state-from an analysis of what mental states a particular act usually, or perhaps necessarily, entails. For example, one cannot imagine a soloist making a proper entrance in a concert without having knowledge of the music as an internal mental state. In fact, that is the traditional way intent has been proved-by circumstantial inference from a particular situation. Thus, John Wigmore says the problem of determining intent should be termed " $[w]$ hat circumstances tend probably to excite a given emotion?"148

The problem is that as soon as one leaves more basic acts and more simple intents, the number of mental states one could reasonably attribute to the actor multiplies. Thus, for simple actsof the type the law most often criminalizes-circumstantial evidence is appropriate and probably accurate. People who inflict grave bodily harm probably intended to do so. Potentially attributable alternate mental states, such as being in a hypnotic trance while committing the act, seem easy to eliminate in this case. As soon as one develops more complex acts, however, certainty falls away and one can eliminate other potentially attributable mental states far less easily. Some types of acts can be done with numerous purposes in mind, and simply observing the act or describing it in purely physical terms will not reveal which of these purposes is, in fact, controlling the actor's mind when the act is being committed. ${ }^{149}$

${ }^{146}$ See People v. Snyder, 104 P.2d 639, 639-640 (Cal. 1940) (holding that where an act becomes criminal only when performed with a particular intent, that intent must be alleged and proved).

${ }^{147}$ See S. REP. No. 138, supra note 112, at 52.

1482 JOHN H. Wigmore, EVIDENCE IN TRIALS AT COMMON LAW $\S 389$, at 417 (Chadbourn rev. 1979) (emphasis omitted). Wigmore identifies three types of circumstantial inferences to show mental states. These are (1) "circumstances tending to excite, stimulate, or bring the emotion [intent, motive] in question into play"; (2) "outward conduct expressing and resulting from the emotion in question"; and (3) "the prior or the subsequent existence of the emotion in question." Id. $\$ 387$, at 416 . Wigmore uses emotion interchangeably with motive, feeling, and passion. See id.

${ }^{149}$ See supra notes 79-83 and accompanying text. 


\section{Which Mental States Does the CRiminal LAW ReQUiRE?}

So far in the discussion, three inferential strategies have been described to infer internal mental state from physical behavior: the argument from analogy, the analysis of statements, and a functional analysis of the usual mental states found in an act. The question then presents itself: In which types of mental states is the criminal law interested? The answer, in general terms, are intents; namely, those culpable mental states which mark "the fundamental distinction we all learned as children, between things done 'on purpose' and those that are not."150

Although this is hardly the place to go into a discussion of action theory and the law, I will present a basic, if not simplistic, paradigm for the way mental states play into behavior so as to clarify later discussion of "motive" and "intent." The paradigm suggests that reasons explain actions, providing a rational explanation of an action given a particular set of beliefs and desires. Aristotle called such forms of explanation "practical reasoning" and formalized it in what he called the practical syllogism:

1. $X$ desired $q$; and

2. $X$ believed that doing $p$ would produce $q$; and

3. $X$ 's doing $p$ was caused by a desire for $q$ and the belief that doing $p$ would produce $q .{ }^{151}$

Thus, in a rough sense, intentional action clearly involves this type of practical reasoning. The criminal law penalizes those with "culpable minds," namely those who act for the wrong reasons and therefore hold culpable beliefs and desires. Thus

1. $X$ desires to murder $Y$; and

2. $X$ believes that pointing a pistol and pulling the trigger would produce Y's murder; and

3. $X$ 's pointing and shooting was caused by his desire for murder and the belief that pointing and shooting would bring it about.

Therefore, the criminal law seeks the accused's mens rea-those beliefs and desires which constitute intent and which furnish the explanatory reasons for the accused's actions. The other minds problem presents the difficulties in figuring out those beliefs and desires, and this Comment has so far outlined three inferential stra-

150 Michael S. MOORE, LAW AND PSYCHIATRY 77 (1984).

${ }^{151} \mathrm{Id}$. at 13 (citation omitted). 
tegies for discovering them. The following Part will discuss motives and intents. It will demonstrate how the beliefs and desires entailed in motive crimes make the other minds problem especially acute.

\section{From Intent to Motive: From Those Claims That ARe REASONABLE TO MAKe ABOUT OTHER MiNDS TO THOSE WhICH ARE LESS REASONABLE}

The discussion has thus progressed so that one might think, along with Judge Posner, that intentional, mentalistic language should be significantly reduced in the criminal law. ${ }^{152}$ After all, if the argument from analogy is as limited as it is, if verbal reports of internal mental states are indeterminate in meaning, and if functional meaning can be arbitrary, how can one meaningfully fill in the mentalistic terms of the Model Penal Code's general requirements of culpability? ${ }^{153}$

Common sense should remedy this crisis. Obviously, many of us do know what's going on in other people's minds; in many cases, it is not that much of a problem. The burden of this Comment is to show that, in general, motives are far more difficult than intents to demonstrate with certainty. In short, to use the language of Part III, the beliefs and desires which constitute motive crimes' mens rea are, in general, more difficult to determine than intent crimes. Motive crimes, therefore, present greater epistemological difficulties than do those of intent-difficulties which may make determinations under motive laws arbitrary.

The argument will proceed in the following manner: first, motive crimes will be distinguished from intent crimes; second, two types of motive crimes will be discussed, using the Violence Against Women Act and hate-crimes statutes; third, several reasons why motive crimes present greater epistemological problems than intent crimes will be set forth, using VAWA and hate crimes as examples.

\section{A. Motive and Intent}

Scholars and courts (including the Wisconsin Supreme Court which struck down the hate-crimes ordinance in State $v$. Mitchell ${ }^{154}$ ) have made much of the distinction between motive and intent. ${ }^{155}$

\footnotetext{
152 See supra note 34 and accompanying text.

${ }^{153}$ See MOdEL PENAL CODE $\$ 2.02$.

154485 N.W.2d 807 (Wis.), rev'd, 113 S. Ct. 2194 (1992), vacated, 504 N.W.2d 610 (1993). See infra part IV.D. for a discussion of Mitchell.

${ }^{155}$ See BLACK's LAW DiCTIONARY 810 (6th ed. 1990) ("Intent and motive should
} 
Professors Wayne LaFave and Austin Scott have given it a classic formulation: "[w]hen $A$ murders $B$ in order to obtain $B$ 's money, $A$ 's intent was to kill and his motive was to get the money. ${ }^{n 156}$ Motive, in other words, goes to the "why" of an action while intent goes to the "what." Or, to phrase it slightly differently, intent goes to the means, while motive goes to the ends.

The distinction between intent and motive is, unfortunately, often not so clear. The problem is that human action is not neatly divided into means and ends-or whats and whys. LaFave and Scott recognize this problem, stating that "intent relates to the means and motive to the ends, but that where the end is the means to yet another end, then the medial end may also be considered in terms of intent." ${ }^{157}$ They leave open the question of how to distinguish between medial ends and "end ends." Motives can be intents and vice versa; it is all a matter of how the action is viewed. ${ }^{158}$ As Douglas Husak says, "insofar as the criminal law is concerned with past intentions, it must also be concerned with motives, since each past intention is a motive. ${ }^{n 159}$

The motive/intent distinction can also be criticized by claiming that it is merely a matter of description. Examine this example taken from a recent defense of hate-crimes legislation:

Consider the bias crime of a racially motivated assault upon an African-American. There are two equally accurate descriptions of this crime: one views the bias as a matter of intent; the other as a separate matter of motive. The perpetrator of this crime could be seen as either:

(1) possessing a mens rea of purpose (or knowing or recklessness) with respect to the elements of assault along with a motivation of racial bias;

(2) possessing a first-tier mens rea of purpose (or knowing

not be confused. Motive is what prompts a person to act, or fail to act. Intent refers only to the state of mind with which the act is done or omitted."). See generally Susan Gellman, Sticks and Stones Can Put You in Jail, But Can Words Increase Your Sentence? Constitutional and Policy Dilemmas of Ethnic Intimidation Laws, 39 UCLA L. REV. 333 (1991).

156 I Wayne R. Lafave \& Austin W. Scott, JR., Substantive Criminal Law $\S 3.6(a)$, at 227 (1986).

${ }^{157}$ Id. at 320.

${ }^{159}$ See Douglas N. HuSak, Philosophy of Criminal Law 145 (1987) ("This use of the means/ends distinction is problematical, for the end of one action may be the means toward another.").

${ }^{159}$ Douglas N. Husak, Motive and Criminal Liability, Crim. JUST. ETHICs, Winter/Spring 1989, at 3, 10. 
or recklessness) with respect to the elements of the parallel crime of assault and a second-tier mens rea of purpose with respect to the element of discriminatory victim selection. ${ }^{160}$

The author here concludes that since the crime of racial assault can be described equally well by intent/motivation and intent alone, the criminal law should not put too much stock in distinguishing between intent and motive. ${ }^{161}$

Well, not so fast. Though some think the notion that motive is irrelevant to criminality is a mere "cliché,"162 the distinction has supporters both in philosophy and the law. For example, G.E.M. Anscombe considered intentions as "mental causes" and did not believe that motives qualify as mental causes: "Motives may explain actions to us; but that is not to say they 'determine', in the sense of causing, actions.... [Rather, t]o explain one's own actions by an account indicating motive is to put them in a certain light. ${ }^{n 163}$ An intent for a particular act can be part of innumerable motives. To use the above example, an intent to assault can be motivated by hatred, a desire to rob, a general need for violence, or racial animus. To assign a motive to an intent requires both a longer story to be told about the actor's subjective mental state and inevitably more interpretation on the jury's part-thus creating ample room for uncertainty and inaccuracy. Because an intent is, however, "closer to the actus reus" and has more direct causal relationship, the intent is easier to read from the act.

In a sense, motives are not as "present" in the act. Motives draw a wider circle, describing acts in broader terms, placing actors in broader frameworks, and requiring more detailed and specific knowledge of subjective mental states. The above example ${ }^{164}$ illustrates the breadth: the second description is longer in sheer word length. Further, "discriminatory victim selection" is a more complicated term than "intending to assault." Discriminatory victim selection only makes sense, to use Anscombe's phrase, "in a certain

${ }^{160}$ Frederick M. Lawrence, Resolving the Hate Crimes/Hate Speech Paradox: Punishing Bias Crimes and Protecting Racist Speech, 68 NOTRE DAME L. REV. 673, 720 (1993).

${ }^{161}$ See id. at 720.

162 Ralph S. Brown, Susan Gellman Has It Right, CRIM. JUST. ETHICS, Summer/Fall 1992 , at $46,46$.

${ }^{163}$ G.E.M. ANSCOMBE, INTENTION 19, 21 (1969).

164 See supra note 160 and accompanying text. 
light. ${ }^{n 65}$ In order to attribute discriminatory victim selection to the actor, you must know the race of the attacker and victim, something about the attacker's personal history, and the history of attitudes and interactions between the two groups. Indeed, by speaking of acts in terms of intents, one narrows the field of description; motive expands the field. Thus, Fletcher says, "[i]f the actor commits larceny intentionally and voluntarily, his accountability and culpability are complete and there is no need to inquire further into his motives." 166 In short, although intents tend to be concerned with an actor's mental attitude towards a spatio-temporally limited event (like an assault or larceny), motives are concerned with the broader picture-the actor's general views, his abstract beliefs, and greater social directives.

Recall the general framework for intentional action of the belief/desire set. Using the previously discussed descriptions of assault, compare the results:

\section{Intents}

1. $X$ wants to assault $P$; and

2. $X$ believes that by punching $P$ he will assault $P$; and

3. $X$ 's assaulting $P$ was caused by his wanting to assault and believing that punching $P$ would produce an assault.

Motives

1. $X$ wants to assault $P$, and $X$ wants to assault a minority; and

2. $X$ believes that by punching $P$ he will assault $P$ and, at the same time, assault a minority member; and

3. $X$ 's assaulting $P$ was caused by his wanting to assault and his wanting to assault a minority and his belief that punching $P$ would produce these ends.

Whatever one thinks about intents and motives, it becomes obvious that motives involve much longer, more verbally complex belief/ desire sets; this is to be expected, for motives have a wider, broader view. Motives require juries to look more penetratingly into defendants' minds. Because they are "longer" and encompass more of an actor's internal mental states, crimes of motive require courts to do more mind reading than plain old crimes of intent. Motives, perhaps, push the other minds problem to the point where it is

${ }^{165}$ ANSCOMBE, supra note 163, at 21.

${ }^{166}$ FLETCHER, supra note $32, \S 6.6$, at 463. 
difficult to have knowledge about other minds. That is a possibility which Part $\mathrm{V}$ will examine. In the meantime, the Comment will turn to a brief description of two motive crimes.

\section{B. The Civil Rights Provision of the Violence Against Women Act: What Motivates Rape?}

The Violence Against Women Act ("VAWA") ${ }^{167}$ grants victims of gender-motivated violent crimes ${ }^{168}$ the ability to lodge a federal civil rights claim. The rationale for making violent crimes against women a civil rights violation is that these crimes reduce victims "to symbols of group hatred [that they] have no individual power to change or escape. The violence not only wounds physically, it degrades and terrorizes, instilling fear and inhibiting the lives of all those similarly situated." 169

${ }^{167}$ The relevant sections of VAWA's current proposed codification read:

(a) Findings.-The Congress finds that-

(1) crimes motivated by the victim's gender constitute bias crimes in violation of the victim's right to be free from discrimination on the basis of gender;

…

(7) a Federal civil rights action as specified in this section is necessary to guarantee equal protection of the laws and to reduce the substantial adverse effects of gender-motivated violence on interstate commerce; .... ....

(c) CAUSE OF ACTION.-A person (including a person who acts under color of any statute, ordinance, regulation, custom, or usage of any State) who commits a crime of violence motivated by gender . . . shall be liable to the party injured, in an action for the recovery of compensatory and punitive damages, injunctive and declaratory relief, and such other relief as a court may deem appropriate.

(d) DEFINITIONS.-For purposes of this section-

(1) the term "crime of violence motivated by gender" means a crime of violence committed because of gender or on the basis of gender; .....

S. REP. NO. 138 , supra note 112 , at $29-30$.

168 "Crime of violence" is thus defined:

(a) an offense that has as an element the use, attempted use, or threatened use of physical force against the person or property of another, or (b) any other offense that is a felony and that, by its nature, involves a substantial risk that physical force against that person or property of another may be used in the course of committing the offense.

18 U.S.C. $\S 16$ (1988).

${ }^{169} \mathrm{~S}$. REP. No. 197 , supra note 112 , at 43 . The 1993 VAWA report states that "[u]ntil women as a class have the same protection offered others who are objects of irrational, hate-motivated abuse and assault, we as a society should feel humiliated and ashamed." S. REP. No. 138, supra note 112, at 49 (citation omitted). 
Senator Joseph Biden, who first introduced VAWA several years ago, ${ }^{170}$ claims that the statute "recognizes, for the first time, a civil rights remedy for victims of crimes 'motivated by gender.'. . Whether an attack is motivated by racial bias or ethnic bias or gender bias, the results are the same." ${ }^{\text {171 }}$ An interesting question presents itself: Is rape enough, in itself, to constitute a civil rights violation? Certainly numerous feminist theorists and commentators have a ready answer of "yes." In fact, the notion that rape is a "political act of violence and domination" is widely accepted in feminist circles. ${ }^{172}$ This theme has become an article of faith among many prominent professional feminists. ${ }^{173}$ Feminists have advanced the theory that rape is an act meant to perpetuate male domination. ${ }^{174}$ The feminist claim seems difficult to maintain in light of a growing body of empirical evidence, coming mostly from researchers of a sociobiological bent, that rape has sexual and reproductive motivations. ${ }^{175}$ Alternative explanations, including those incorporating an economic analysis, have also been suggested. ${ }^{176}$

170 VAWA was first introduced in 1990 as S. 2754, 101st Cong., 2d Sess. (1990).

171 Joseph R. Biden, Domestic Violence: A Crime, Not a Quarrel, TRIAL, June 1993, at 56,59 .

${ }^{172}$ Craig T. Palmer, Twelve Reasons Why Rape Is Not Sexually Motivated: A Skeptical Examination, $25 \mathrm{~J}$. OF SEX RESEARCH 512, 513 (1988).

${ }^{179}$ See, e.g., Catharine A. MacKinnon, Reflections on Sex Equality Under Law, 100 YALE L.J. 1281, 1302 (1991) ("Rape is an act of dominance over women that works systemically to maintain a gender-stratified society in which women occupy a disadvantaged status as the appropriate victims and targets of sexual aggression." (citation omitted)).

${ }^{174}$ See, e.g., SUSAN BrownmiLler, AGaINST OUR Will 15 (1975) (stating that rape "is nothing more or less than a conscious process of intimidation by which all men keep all women in a state of fear"); LORENNE M.G. CLARK \& DEBRA J. LEWIS, RAPE: THE PRICE OF COERCIVE SEXUALTTY 27 (1977) (supporting the feminist view "that rape is simply the ultimate weapon which men use to exercise power over women"); Alison M. JAGGer, FEminist Politics and human Nature 262 (1988) ("Radical feminists see rape as a political act which is oppressive on many levels.").

175 The thesis states that rape is an alternate reproductive strategy used by lowstatus males who cannot find mates using the other two reproductive strategies, honest courtship and seduction-deception. See Randy Thornhill \& Nancy W. Thornhill, Human Rape: An Evolutionary Analysis, 4 ETHOLOGY \& SOCIOBIOLOGY 137, 138 (1983) (citing W.M. Shields \& L.M. Shields, Forcible Rape: An Evolutionary Perspective, 4 ETHOLOGY \& Sociobiology 115 (1983)).

${ }^{176}$ The feminist theories for the causation of rape compete on a crowded field. According to Judge Posner, "[c]ontrary to a view held by many feminists, rape appears to be primarily a substitute for consensual sexual intercourse rather than a manifestation of male hostility toward women or a method of establishing or maintaining male domination." RICHARD A. POSNER, SEX AND REASON 384 (1982) (footnotes omitted). Posner suggests a rational economic actor analysis in which the 
Yet before the motivation claim can be answered, there is a genuine question as to whether VAWA has any conscious mens rea requirement at all. If there is a mens rea requirement, there is a further question as to what it might be. The language frustrates in its vagueness, and the legislative history is tangled, so any conclusions about VAWA's mens rea must be tentative and, according to one supporter of the bill, can be fully developed only by the courts. ${ }^{177}$ Nonetheless, potential mens reas will be discussed so as to show in Part $\mathrm{V}$ why these mens rea requirements are much more difficult to establish than those of traditional intent crimes.

What does it mean that a rape was "motivated by gender"? What mental state must accompany the act of rape so that it is considered so motivated? As stated above, VAWA, in its most recent form, defines a "crime of violence motivated by gender" as a "crime of violence committed because of gender or on the basis of gender; and due, at least in part, to an animus based on the victim's gender."178 This language suggests two main directions for looking at the mens rea requirement: the animus requirement, as defined in the current codifications of the civil rights statutes, ${ }^{179}$ and the intent requirement under Title VII of the Civil Rights Act of $1964 .{ }^{180}$

\section{The Animus Requirement: What Does It Mean and How Could It Be Proved?}

The legislative history points to 42 U.S.C. $\$ 1985(3)$ and related civil rights law as well as Title VII in order to show motivation. ${ }^{181}$

incidence of rape is related to the scarcity and availability of sex. See id. at 385-86.

Supporters of VAWA, however, seem conspicuously hostile to the notion that rape may have a sexual component. For instance, at least one writer has used Posner's views as an example of the persistent prevalence of sexism and sexual stereotyping on the federal bench. See W.H. Hallock, Note, The Violence Against Women Act: Civil Rights for Sexual Assault Victims, 68 IND. L.J. 577, 601 n.162 (1993).

${ }^{177}$ See generally The Civil Rights Tille of the Violence Against Women Act: Hearings Before the Subcomm. on Civil and Constilutional Rights of the House Comm. on the Judiciary, 103d Cong., 1st Sess. (1993) [hereinafter Civil Rights Title Hearings] (statement of James P. Turner, Acting Assistant Attorney General, Civil Rights Division, U.S. Department of Justice).

${ }^{178}$ H.R. 3355, supra note $20, \S 3402$ (d).

${ }^{179}$ See 42 U.S.C. \$ 1985(3) (1988).

${ }^{180} 42$ U.S.C. $\$ 2000 \mathrm{e}-2(\mathrm{a})(1)$ (1988).

${ }^{181}$ See S. REP. NO. 138, supra note 112, at 51-53. Like the statutes on which it is modeled, 42 U.S.C. $\$ 1981$ (1988 \& Supp. IV 1992) and 42 U.S.C. $§ 1985(3)$, this section of VAWA reaches gender-based discrimination by private persons and by persons acting under color of state law. See H.R. 3355, supra note 20, § 3402(c). 
Under the case law, the animus standard has been developed in the racial context and, to a degree, in the gender context.

\section{Animus Under 42 U.S.C. § 1985(3)}

According to its most prominent judicial interpretation, 42 U.S.C. $\S 1985(3)$ requires that "[t]he language requiring intent to deprive of equal protection, or equal privileges and immunities, means that there must be some racial, or perhaps otherwise classbased, invidiously discriminatory animus. ${ }^{182}$ The question presents itself: Is the rape act sufficient, in itself, to demonstrate such animus? Supporters of VAWA often claim that the act of rape itself constitutes a civil rights violation. In the following Section, this claim will be examined.

This specific intent requirement of $\S 1985(3)$ has been reaffirmed in Bray v. Alexandria Women's Health Clinic, ${ }^{183}$ in which the Supreme Court held Operation Rescue's efforts to obstruct abortion clinics did not constitute "class-based, invidiously discriminatory animus" against women. ${ }^{184}$ Writing for the majority, Justice Scalia noted that in order to avoid the "constitutional shoals that would lie in the path of interpreting $\S 1985(3)$ as a general federal tort law, ${ }^{185}$ there must be a specific animus requirement-in this case, there must have been an animus against women. Further, Scalia noted that this intent requirement could be inferred if the object of its animus were so irrational that it could be seen only as a mask for another animus: "A tax on wearing yarmulkes is a tax on Jews." 186 He ruled, however, that "opposition to voluntary abortion cannot possibly be considered such an irrational surrogate for opposition to ... . women." 187

Under this formulation, the intent requirement of VAWA would be very specific and would look something like this:

1. $X$ wants to have sexual intercourse with $P$, and $X$ hates $P$ because she is a member of a certain class, namely women.

2. $X$ believes that by raping $P$ he will have sexual intercourse with $P$ and, at the same time, express his hatred for a class.

${ }^{182}$ Griffin v. Breckenridge, 403 U.S. 88, 99 (1971).

183113 S. Ct. 753 (1993).

${ }^{184}$ Id. at 759 (citing Griffin, 403 U.S. at 102).

${ }^{185} I d$. (citing Griffin, 403 U.S. at 102).

${ }^{186}$ Id. at 760 .

${ }^{187}$ Id. 
3. $X$ 's raping $P$ was caused by his wanting sexual intercourse, his hatred of women as a class, and his belief that raping $P$ would result in sexual intercourse and an expression of his hatred.

Thus, the animus requires a degree of "mind reading" much greater than for the crime of rape.

\section{VAWA's Title VII Connection: Is There an Intent Requirement?}

The Title VII approach is in complete opposition to the animus requirement, yet the legislative history clearly points to Title VII as providing the method of proof of motivation which VAWA would use. The legislative history states that "[t]he phraseology 'motivated by,' 'because of,' 'on the basis of,' or 'based on' sex or gender is used interchangeably in the case law discussions of Title VII. This body of case law will provide substantial guidance to the trier of fact in assessing whether the requisite discrimination was present. ${ }^{n 188}$

Title VII case law has established that knowledge of any mental state is not required to show discriminatory motive. ${ }^{189}$ Of the two broad categories of Title VII discrimination, disparate impact and disparate treatment, ${ }^{190}$ only the latter requires a showing of intent. ${ }^{191}$ Under disparate impact, however, the plaintiff must show that a particular employment practice produces a disparate impact pattern in hiring; the employer's defense is a showing of business necessity. ${ }^{192}$ If an employer has a practice which a court

${ }^{188}$ S. REP. NO. 197 , supra note 112 , at 50-51. The 1993 VAWA report notes that the "definition of gender-motivation is based on Title VII." S. REP. NO. 138, supra note 112 , at 52 .

${ }^{189}$ See, e.g., Griggs v. Duke Power Co., 401 U.S. 424, 431-32 (1971) ("The Act proscribes not only overt discrimination but also practices that are fair in form, but discriminatory in operation. .. . Congress directed the thrust of the Act to the consequences of employment practices, not simply the motivation." (emphasis omitted)); McKinney v. Doles, 765 F.2d 1129, 1138 (D.C. Cir. 1985) ("[A]ny ... unequal treatment of an employee or group of employees that would not occur but for the sex of the employee may ... comprise an illegal condition of employment under Title VII.").

190 See Michael J. Zimmer et al., CaSes and Materials on Employment DisCRIMINATION 310-13 (2d ed. 1988).

${ }^{191}$ Moreover, under disparate treatment, the prima facie case can be made without reference to intent. See McDonnell Douglas Corp. v. Green, 411 U.S. 792, 802 (1973) (stating the four-part prima facie case of racial discrimination).

192 See David A. Cathcart \& Mark Snyderman, The Civil Rights Act of 1991, in THE Civil RIGHTS ACT OF 1991, at 1, 55 (ALI-ABA Video Law Review Study Materials, Feb. 13, 1992). Under current law, business necessity requires a showing "that the challenged practice is job related for the position in question and consistent with 
fails to deem related to a business function, that employer is liable under Title VII-regardless of his intent or lack of intent to discriminate. The legislative history, in fact, offers disparate impact evidence as proof of gender-based motivation in rape. ${ }^{193}$ The Senate Report states that "the victim's lawyers would prove . . . that the attacker did not kidnap and rape men, but had a long history of attacking women." ${ }^{194}$ In other words, if a man only rapes women, he violates VAWA, but if he rapes men and women-and is therefore an equal opportunity rapist-he is exempt. ${ }^{195}$

\section{Hate Crimes: Mitchell, Motive, Intent, and Knowing Other Minds}

Much of the recent debate on hate crimes and penalty-enhancement statutes has revolved around the constitutional issues of whether such laws violate First Amendment guarantees of free speech and thought or are void on grounds of vagueness or overbreadth. ${ }^{196}$ In Wisconsin $v$. Mitchell, ${ }^{197}$ a unanimous decision affirmed the constitutionality of hate-crimes statutes. The argument was clear: citing legal scholars LaFave and Scott, ${ }^{198}$ Chief Justice Rehnquist noted that culpable motives often play a key role in sentencing. ${ }^{199}$ Moreover, the argument that hate-crimes statutes should not punish motive is not compelling, because motive plays a role in other laws that have been upheld. ${ }^{200}$ In short, the state is free to punish crimes differently depending on the motive if it feels that the same crime, if differently motivated, differs in its perceived harms.

business necessity." Id. (quoting the Civil Rights Act of 1991, Pub. L. No. 102-166, 105 Stat. 1071, codified at 42 U.S.C. $\$ 1981$ (a) (Supp. IV 1992)).

${ }^{193}$ See S. REP. NO. 197, supra note 112 , at $50-51$.

${ }^{194} \mathrm{Id}$. at 50.

${ }^{195}$ See Wendy R. Willis, Comment, The Gun Is Always Pointed: Sexual Violence and Title III of the Violence Against Women Act, 80 GEO. L.J. 2197, 2224 (1992).

${ }^{196}$ See, e.g., Gellman, supra note 155, at 354-79.

197113 S. Ct. 2194 (1993).

${ }^{198}$ See LAFAVE \& SCOTT, supra note $156, \S 3.6(\mathrm{~b})$ ), at 324 ("Motives are most relevant when the trial judge sets the defendant's sentence, and it is not uncommon for a defendant to receive a minimum sentence because he was acting with good motives, or a rather high sentence because of his bad motives.").

${ }^{199}$ See Mitchell, $113 \mathrm{~S}$. Ct. at 2199.

${ }^{200}$ See, e.g., 42 U.S.C. $\$ 2000 \mathrm{e}-2(\mathrm{a})(1)$ (making it unlawful for an employer to discriminate against an employee or potential employee "because of such individual's race, color, religion, sex or national origin"). 
The Wisconsin Supreme Court, on the other hand, found the statute unconstitutional because it criminalized thought. Drawing heavily on Professor Susan Gellman's article, the court concluded that the Wisconsin penalty enhancement statute was overbroad, violating protected First Amendment rights. ${ }^{201}$ Accepting the LaFavian distinction between intent and motive, the court concluded that the statute punished motive and therefore violated the First Amendment: "[The Wisconsin hate-crimes statute gives] an additional punishment for the defendant's motive in selecting the victim. The punishment of the defendant's bigoted motive by the hate-crimes statute directly implicates and encroaches upon First Amendment rights." 202

Gellman has used this distinction to assert that "[u]nlike purpose or intent, motive cannot be a criminal offense or an element of an offense." 203 Making motive a crime actually criminalizes thought, not action, and thus violates the First Amendment guarantee of individuals' freedom of thought. ${ }^{204}$

Interestingly, the court noticed the evidentiary problem of showing motive:

The conduct of "selecting" is not akin to the conduct of assaulting, burglarizing, murdering and other criminal conduct. It cannot be objectively established. Rather, an examination of the intentional "selection" of a victim necessarily requires a subjective examination of the actor's motive or reason for singling out the particular person against whom he or she commits a crime. ${ }^{205}$

Present in the court's thinking is the notion that there is something different about motives-or, in particular, the type of complex intents which hate crimes entail. The next Part will examine this possibility.

${ }^{201}$ See Wisconsin v. Mitchell, 169 Wis. 2d 153, $157-58$ (1992).

202 See id. at 166.

${ }^{203}$ Gellman, supra note 155 , at 364.

${ }^{204}$ See Wooley v. Maynard, 430 U.S. 705 (1977) (holding a New Hampshire state statute invalid because it could not require citizens to display state motto containing an ideological message without violating the First Amendment); see also Abood v. Detroit Bd. of Educ., 431 U.S. 209, 234-35 (1977) (" $[\mathrm{A}] \mathrm{t}$ the heart of the First Amendment is the notion that an individual should be free to believe as he will, and that in a free society one's beliefs should be shaped by his conscience rather than coerced by the State.").

${ }^{205}$ Mitchell, 169 Wis. 2d at 166. 


\section{MOTIVE CRIMES AND INTENT CRIMES: Do THE Former Present an INTRACTABle OTHER MindS Problem?}

An obvious argument presents itself: simply because motive crimes require more knowledge about other minds than do intent crimes, motive crimes are suspect. This argument has a good deal of punch. Justifying knowledge about other minds is deeply problematic, so the criminal law should use mentalistic language sparingly. While intent crimes seem to use mentalistic terms in ways few would find difficult to accept, motive crimes cross the other minds Rubicon where knowledge is more problematic: few would dispute that one who attacks another with a knife intends to kill him, but for what motive this act is committed (jealousy, anger, unresolved childhood sexual tension, racial animus, generally violent temperament) is a far more difficult and complicated question. Yet beyond this general argument, there are many more specific reasons why motive crimes present greater problems than intent crimes. To bring out the differences, I will draw on the previous Section's discussion of penalty-enhancement crimes for hate crimes and VAWA.

\section{A. The Argument from Analogy Fails for Motive Crimes' Complex Motivational States}

The first difference has to do with the way criminal statutes are usually constructed. Take a hate crime and a typical concomitant crime-assault committed because of racial animus. The mens rea required for assault is "purposely, knowingly or recklessly causes bodily injury to another." ${ }^{206}$ Using the argument from analogy, this is generally not too difficult to determine. As children (and sometimes as adults), most of us have gotten into physical fights; as adults we observe what types of instruments and physical movements can cause bodily injury-so that one can conclude that if one uses a brick to smash another's head, one probably intends to cause bodily injury. The argument from analogy works well because we all share the similar experiences of living in the world, of having bodies, and of knowing and experiencing the types of intents we have when we hit or punch or pummel. As human beings we generally share the necessary experience so that the other minds problem does not present an enormous obstacle in determining

${ }^{206}$ MODEL PENAL CODE § 211.1(1)(a). 
assault's mens rea. As a general rule, it seems fair that for crimes like assault, which center around simple acts or intentional basic physical movements as the mens rea requirement, the argument from analogy works quite well.

Consider, however, the other minds problem of whether a defendant's action was motivated by racial animus. The argument from analogy works less well here. While many believe that racial prejudice is so endemic to our society that all Americans experience prejudice, few act in violence on racial motivations. Few know what it is like to act violently from racial animus; thus, it becomes impossible to analogize one's own mental states onto defendants charged with such animus.

\section{B. The Covariant Relationship Between Crime and Animus}

A second problem is that of the covariant relationship between racial animus and general violent, criminal nature. Notice that the hate-crimes laws require that the criminal act be motivated by racial animus. Otherwise, hate-crimes laws would merely punish racists who happen to commit crimes, thus running afoul of the First Amendment. ${ }^{207}$ Hate-crimes statutes require courts to separate out a defendant's general political or social views and to concentrate on the act itself.

This distinction is essential; without it the laws would penalize thoughts. The problem is that such a separation is difficult, to say the least, and considering the other minds problem, it may often be impossible. How can one distinguish between, on one hand, the racist who happens to assault people and expressed himself as a racist before an attack and, on the other hand, a racist whose attack was actually motivated by racial animus? Far from being academic, this distinction keeps hate crimes from being thought crimes. Moreover, whenever courts make mistakes because of their essentially limited ability to infer mental states (and because of the unverifiable nature of intents, no one will ever be able to tell if mistakes have been made), then hate crimes will be thought crimes.

${ }^{207}$ Lawrence, supra note 160 , at 698 (the "commission of a bias crime may be proscribed and constitutes a crime ... which ... may be punished. The same cannot be said of racist speech.") 


\section{Animus as a "But-For" Cause}

The model of the practical syllogism for intentional or purposive action requires that the actor believe and desire certain things about the act. ${ }^{208}$ Certainly, there are other causes for the act other than the actor's intention. Say the crime is theft. A white supremacist attends a neo-Nazi rally. Afterwards he drinks a bit and then decides to rob someone. His victim happens to be African American. Following this line of thought, racial animus is a but-for cause for a particular act; had the attacker not had racial thoughts, the attack would not have happened. Nonetheless, the practical syllogism which the actor went through at the time of the attack had nothing to do with race.

Consider slightly altered Mitchell ${ }^{209}$ facts. Say that the attackers were violent after seeing a film and perhaps even harbored racist feelings. The young men saw a white youth and pursued him. Say further that the chase is long and exhausting, and the attackers would have given up except for one who urges them on, telling them that they would be unathletic sissies if they allowed the victim to outrun them. The attackers finally catch up and beat the victim. Flushed with anger at the victim's flight, they have forgotten their racial animus and are only concerned with showing their stubborn victim that they are not to be bested. When the young men finally get around to beating their victim, they are motivated by anger, annoyance, and the need to save face among their comrades. Race does not play into the practical syllogism which accompanies the actual assault.

If this is the case, then the young men are not motivated by racial factors in their assault. The practical syllogisms in the attackers' minds which controlled the criminal action of assault had nothing to do with racial animus, for their belief/desire set did not contain racial animus-even though racial animus was a but-for cause of the attack.

If the criminal law punishes mens rea only when it "accompan[ies] the act that produces or threatens the harm, ${ }^{210}$ then the

${ }^{203}$ See supra part III.

${ }^{209}$ Mitchell v. Wisconsin, 113 S. Ct. 2194 (1993). The defendant in Mitchell watched the film Mississippi Burning, which focuses on racial conflict, shortly before attacking his victim. See id. at 2196; see also supra part IV.D (discussing Mitchell in for detail).

${ }^{20}$ Sanford H. Kadish \& Steven Schulhofer, CRIminal Law and ITS PROCESSES: CASES AND MATERIALS 217 (1989 5th ed.). 
hypothetical Mitchell attackers' racial animus but-for cause cannot be punished. As a practical matter, it may often be impossible to distinguish those cases in which racial animus functions as a but-for cause from cases in which it acted as the motivating mental factor that accompanied the outlawed harm. If this is the case, then hate crimes merge with thought crimes.

\section{The Incompleteness of Verbal Evidence and Circumstantial Evidence}

The second problem is that verbal evidence can establish only that one is a bigot, not that bigotry served as the motivating factor in a hate crime. Even if an actor uttered racist speech shortly before the crime, it establishes him only as a racist and sheds little light on whether the act itself was racially motivated. Thus, even if one were able to ascertain the intended meaning of an epithet, ${ }^{211}$ it hardly proves that racist motivations played into the practical syllogism which controlled the criminal act. Although epithets are highly suggestive, if not dispositive, of general viewpoint and approach (perhaps even a but-for motive), these viewpoints, in themselves, cannot be criminal, for such a criminalization would be tantamount to criminalizing thought. The criminal act, itself, must be motivated by such animus. Such fine, yet essential distinctions may be lost on the jury. The problem with motive crimes, therefore, is that verbal evidence-one of the key types of evidence used for their proof-can show only general attitude; ${ }^{212}$ it cannot show whether the act itself was so motivated.

\section{The Verbal Sophistication of Motive: The Specificity of the Animus Requirement}

Wittgenstein states that "[i]f a lion could talk, we could not understand him." ${ }^{213}$ In this vein, he writes:

A dog believes his master is at the door. But can he also believe his master will come the day after to-morrow?-And what

${ }^{211}$ Part II.B.3, supra, shows that this is no easy task.

212 See James B. Jacobs, Should Hate Be a Crime?, 113 PUB. INTEREST 3, 8 (1993) ("Examinations [often used in hate-crimes trials] seem more likely to turn hate crime trials into character tests of the most pernicious kind and to widen social divisions.").

213 Ludwig WITtgenstein, Philosophical. InVestigations 223 (G.E.M. Anscombe trans., 1974). 
can he not do here?-How do I do it?-How am I supposed to answer this?

Can only those hope who can talk? Only those who have mastered the use of a language. That is to say, the phenomena of hope are modes of this complicated form of life. ${ }^{214}$

I think that Wittgenstein is stating, in his characteristic way, that certain behaviors and actions-like hoping-are only possible to those creatures who possess the verbal sophistication to make them possible. Thus, dogs cannot hope, and lions cannot speak in a humanly comprehensible language because such activities involve a verbal complexity which dogs and lions do not have; the act, in a sense, is defined by the verbal complexity.

If we accept the notion that practical syllogisms are, in some way, the controlling factors over our behavior, then an actor must have a degree of verbal sophistication in his intents in order to intend certain intents. Just as a dog cannot hope, a factory owner who never heard of Marx cannot intend to produce an alienated consciousness among the proletariat (even though he may do precisely that and may understand he is doing so after explanation from a Marxist intellectual). In short, an actor's beliefs and desires must be sufficiently complex in order to intend these sophisticated acts.

If one recalls the comparison of the belief/desire sets for motivation and intention, one remembers that the motive's belief/ desire set was both longer and more complicated. ${ }^{215}$ Indeed, because motives have a more general, wider framework, their description is more complicated. Intents, which concentrate on smaller slices of action, are simpler and based on simpler acts.

The question then presents itself: Do motive crimes specify such complicated motives that actors cannot fairly be held to have them? I think this question comes to the fore in VAWA, which requires "an animus based on the victim's gender. ${ }^{216}$ It is not at all clear what that animus would mean; following Bray $v$. Alexandria Women's Health Center, ${ }^{217}$ it would mean something like this:

1. $X$ desires to have sexual intercourse with $Y$ and thus to humiliate women as a group; and

214 Id. at 174.

${ }^{215}$ See supra part IV.A.

${ }^{216}$ H.R. 3355, supra note 20, § 3402(d)(1).

217113 S. Ct. 753 (1993). See supra notes $183-87$ and accompanying text for a discussion of Bray. 
2. $X$ believes that raping $Y$ will allow him to have sexual intercourse with $Y$ and humiliate women as a group; and

3. $X$ 's raping $Y$ was caused by his desire to have sexual intercourse and to humiliate women as a group and his belief that raping $Y$ would accomplish these ends.

It seems at least possible that not all rapists go through this process. It seems probable that their motivations and thought process are not that well-articulated. It seems possible that rapists intend to commit the physical act of rape and even harbor inchoate hostility towards women, but the practical syllogism associated with their criminal act does not even approach the verbal complexity of the animus requirement. The conscious, well-defined animus may not be present-even though, if, like the factory owner, they might be made to understand rape in the terms of animus after some time in therapy. Thus, crimes of motivation run the risk of criminalizing intents which the actor does not have but which others believe, as a theoretical matter, are suggested in the act. The legislative history and intellectual framework suggests that the act of rape itself would be demonstrative of antiwomen class animus. ${ }^{218}$ If this approach is taken, VAWA may punish actors for acting on motivations which they do not, in fact, possess.

\section{Problems of the Unconscious Motive}

Another problem with motive crimes is that many believe that some motives and mental processes are unconscious. ${ }^{219}$ VAWA, for instance, potentially penalizes unconscious motivation. ${ }^{220}$ This presents a tremendous epistemological dilemma-how does the Court determine motives which are unknown to the actor himself?

Freudian analysis attempts to do just that-with limited success. As Professor Stephen Morse notes, "the role of psychodynamic

${ }^{218}$ In fact, some of the earlier versions of VAWA specifically enumerated rape as a crime of violence motivated by gender and eliminated the need for proof of gender motivation for these crimes. "[T]he term 'crime of violence motivated by gender' means any crime of violence, as defined in this section, including rape." H.R. 5468, 101st Cong., 2d Sess. § 302(d)(2) (1990).

${ }^{219}$ See SIGMIUND FREUd, INTRODUCTORY LECTURES ON PSYCHO-ANALYSIS 353 (James Strachey trans. \& ed., 1966) (" $[P]$ sychological research of the present time . . . seeks to prove to the ego that it is not even master in its own house, but must content itself with scanty information of what is going on unconsciously in its mind.").

${ }^{220}$ Although the 1993 VAWA has an animus requirement, there is no guarantee that courts will require a conscious animus. Just as Title VII does not require conscious intent, neither may VAWA, which is modeled after Title VII. 
psychology in general is not sufficiently scientifically verified for the law to accept it as relevant in the criminal process. Speculations based on psychodynamic psychology, judged as scientific causal accounts of behavior, are not 'informed' but idle."221 Indeed, if crimes of motive transform the witness stand into the analysand's couch and the jurors into analysts, that, in itself, may be good reason not to criminalize motive. Speculations into hidden motivations unknown to the actor are, well, speculative, and probably do not meet the normative standards required for a fair trial. Using unconscious motives, the other minds problem simply becomes the "mind" problem-not only do others have limited access to the defendant's mind, but the defendant, himself, has limited access to his own mind.

There is also an ethical concern for not using unconscious drives to establish culpability. If we view culpability as acting for the wrong reasons, then it is a serious question whether one can be held morally responsible for reasons which are, at least at the time of the event, unconscious. It certainly does not square with notions of fairness for a court to tell a defendant, "At the time you committed the act, you had these beliefs, desires, and consequent intent-even though you did not know you had them." Yet, that is precisely what crimes of motive invite courts to do.

\section{E. The Revenge of the Other Minds Problem?}

In 1980, New York City responded to a spate of hate crimes by establishing the Bias Crime Unit to "monitor and investigate acts committed against a person, group, or place because of race, religion, or ethnicity." 222 The New York Police Department's ("NYPD") definition of hate crime requires that the act be motivated by a particular bias. ${ }^{223}$

Interestingly, the Bias Unit's pronouncement “on whether any particular crime is bias-motivated itself has become a volatile political issue which could exacerbate or even set off conflict." 224

${ }^{221}$ Stephen J. Morse, Failed Explanations and Criminal Responsibility: Experts and the Unconscious, 68 VA. L. REV. 971, 1017-18 (1982).

${ }^{222}$ James B. Jacobs, Rethinking the War Against Hate Crimes: A New York City Perspective, CRIM. JUST. ETHICs, Summer/Fall 1992, at 55, 55.

${ }^{223}$ The NYPD defines a bias incident as "[a]ny offense or unlawful act that is motivated in whole or in part by a person's, group's or place's identification with a particular: race, religion, ethnicity or sexual orientation." Id. at $60 \mathrm{n} .3$ (citing BIAS INCIDENT INVESTIGATION UNIT, NEW YORK CITY POLICE DEP'T 8 (1991)).

${ }^{224}$ Id. at 57; see also William K. Rashbaum \& David Kocieniewski, Early Release: 
In late 1992, in the wake of numerous complaints, the NYPD instituted a new procedure in which an officer "will not 'deem' an incident bias-related. Rather the officer will declare it a 'possible bias incident' and turn it over to the NYPD's Bias Unit which will make a determination. The unit's work will be reviewed quarterly by an NYPD panel. ${ }^{n 25}$

The NYPD's history places the difference between bias crimes and other crimes in high-relief. When a thief steals or a murderer kills, there is no administrative structure to determine whether the officer who first reports the incident "deemed" it correctly. Yet, in the bias-crime area, the officer who first appears on the scene is not trusted to determine whether the crime occurred. Bias crimes may exist in a different epistemological plane where certainty is much rarer; the proof is in the practice.

\section{CONCLUSION: WHAT IS AT STAKE?}

Why should one care about VAWA or hate-crimes legislation? Why should it make a difference whether rapists or other criminals receive extra sentencing or additional civil penalties? After all, most people rightly feel little sympathy for either rapists or bigoted criminals. The integrity of the judicial system, however, requires that it neither be arbitrary nor impinge on freedom of thought. The burden of this Comment has been to show that VAWA and hate-crimes statutes presume knowledge is possible in areas in which such knowledge is virtually always suspect and in which the threat of punishing thought is always present. These laws feed a legal vanity that human motivations are transparent when, in fact, they are opaque. When courts make decisions based on inherently speculative knowledge, their decisions will inevitably be seen as arbitrary. Laws which require judges and juries to make such uncertain determinations can only hurt the judicial process, especially when errors lead to the punishment of thought.

Since the time of Dinah, ${ }^{226}$ all civilized societies have condemned rape, and American society-especially considering its tortured history of racial relations-must condemn racially-inspired

DA Admits Error in Freeing Suspect, N.Y. NEWSDAY, July 23, 1993, at 3 (describing the possible involvement of the Bias Unit in prosecuting an insane woman who pushed people in front of subways and who made an antiwhite remark).

${ }_{225}$ Editorial, The Bias Tag: Use It Carefully, N.Y. NEwSDAY, Dec. 23, 1992, at 44.

${ }^{226}$ See Genesis 34:7 (" $[\mathrm{H}] \mathrm{e}$ had wrought folly in Israel in lying with Jacob's daughter; which thing ought not to be done."). 
crimes. Nonetheless, VAWA and hate-crimes legislation are not the vehicles to achieve these ends. Because they present jurors and judges with motivation's evidentiary vacuum, they invite courts to impose their own personal, perhaps often political, views onto the inner workings of defendants' minds. Because the evidence used for determining motive is so problematic, judges and juries may simply pick between conflicting views of society and humanity instead of seriously examining the facts before them, because the facts before them, as the Comment shows, are perhaps always insufficient to determine motive. These laws are, in a sense, politicsby-other-means, inviting judges and jurors to impose their own world views and not examine the facts of the case. To paraphrase Karl Kraus, ${ }^{227}$ these laws claim to be the cure-but are, in fact, the disease.

${ }^{227}$ See Paul Hofmann, The VIENNESE: SPlendor, Twilight, AND EXILe 130 ( ${ }^{\circ} \mathrm{Of}$ the many aphorisms that Karl Kraus crafted, probably the most famous is his assertion that 'psychoanalysis is the mental disease whose therapy it believes itself to be." $)$. 
